\title{
Water Tariffs in Spain
}

Fernando Arbués and Marián García-Valiñas

\section{Summary}

In the current context of climate change, water scarcity has become the centre of an intense debate in recent years. Spain is a country affected by strong regional differences in terms of weather; as such, the quality and availability of water resources vary widely depending on the area, and the country is plagued by droughts and quality related problems. Nevertheless, urban water prices in Spain are among the lowest in the European Union. Moreover, it is a federal country where sub-central governments (regional and local) are autonomous entities with different responsibilities in the design of water policies. The extremely atomized local panorama and the strong power of the regional governments have led to a highly complex system with a wide range of water price levels and structures. Since the heterogeneity is huge, this chapter focuses on the tariffs related to supply water service in the largest 15 Spanish cities. In general, urban water tariffs commonly distinguish between residential and non-residential users. Additionally, there are usually specific tariffs for different customer categories within both the residential and non-residential users, which are not always justified in terms of the equity principle. It is important to note that in most cities the eligibility criteria for these special tariffs usually adds more complexity to the tariff system and adversely affects horizontal equity. All these factors contribute to the great complexity of Spain's water-pricing map. The heterogeneous tariff system found in most Spanish cities runs counter to equity principles and can send the wrong signal to users about water scarcity, thereby hindering compliance with the resource sustainability objective. Thus, a simplification of the tariff system is required in most Spanish cities.

\section{Keywords}

Water tariffs, Urban users, Spain, General tariff, Special tariffs, residential uses, non-residential uses 


\section{Introduction}

In the context of climate change, water scarcity has become the centre of an intense debate in recent years, as there is not enough supply to meet demand in many urban areas. Issues of water scarcity, water stress and quality have attracted increasing attention because of their significant economic, social and environmental implications (OECD, 2003, 2013). This calls for a special focus on water management procedures, especially those based on demand-side policies. Examples of demand-side measures that are being applied in many areas include regulations, education and information campaigns and, above all, pricing measures. Additionally, water is considered a merit good, so public policies should guarantee that everybody receives a minimum amount of water. In 2010, the United Nations explicitly recognized the human right to water (United Nations, 2010). In this respect, pricing policies are also playing a significant role in the attempt to accomplish these objectives.

The need for an appropriate tariff design is an issue that is highlighted in the Water Framework Directive (WFD) 2000/60/EC of the European Parliament and of the Council of 23 October 2000 (EC, 2000), which establishes that Member States shall ensure "that water-pricing policies provide adequate incentives for users to use water resources efficiently" (EC, 2000, Art. 9). Nevertheless, water tariff design is a complex process involving multiple factors related to efficiency, equity, cost recovery and the environment, among others. To reconcile these various objectives, water managers need to design different tariffs for different types of users. Furthermore, given the normative nature of tariff design, it is subject to intense social debate about its effects on equity and water conservation.

As a European Union Member State, Spain must comply with the WFD, but it is also committed to achieving United Nations aims. However, Spain is a country affected by strong regional differences in terms of weather; as such, the quality and availability of water resources vary widely depending on the area, and the country is plagued by droughts and quality related

problems (Lopez-Gunn et al. 2012; Willaarts et al. 2014). Moreover, it is a federal country, with 
both central and sub-central governments actively participating in the design of public water policies. All these factors contribute to the complexity of Spain's water-pricing map.

This chapter is aimed at reviewing the water tariffs applied in Spanish cities, and includes a discussion on how municipalities charge for water services destined for different uses. The work is structured as follows. Section 2 presents a general discussion about equity and efficiency objectives in the water sector, describing the role of pricing policies. Section 3 provides a detailed description of water tariffs for residential and non-residential uses in the 15 largest cities in Spain. In this respect, in-depth information and critical discussion on both general and special tariffs are provided. Section 4 closes the chapter with some proposals for the reform of waterpricing policies in Spain.

\section{Equity and Efficiency Objectives in The Water Sector: The Role of Pricing Policies}

From the water supplier's perspective, the main objective of tariff design is cost recovery or, at least, to ensure specific revenue target. Nevertheless, water tariffs are a powerful management tool that can be used to achieve several objectives. In this line, the United Nations' Sustainable Development Goal (SDG) number 6 calls for universal and equitable access to safe and affordable drinking water for all by 2030. Moreover, it is aimed at improving water-use efficiency over time (United Nations, 2018). Some significant trade-offs among criteria exist. For example, the equity aim is clearly conflicting with cost-recovery objectives, since the existence of "social" tariffs could erode water supplier total revenues. Additionally, if we are not careful when including the equity criterion in water tariffs, we could foster overconsumption, reducing efficiency and sustainability levels. Even though there are several important objectives when designing water prices, such as cost-recovery or environmental aims, equity and efficiency are traditionally considered two of the main pillars of public water policies (OECD, 2003; 2010). Consequently, we will focus our attention on these two latter criteria.

Regarding equity, some key principles can be identified. On the one hand, the benefit principle establishes that, for the same quantity and quality of water supplied, different users 
should have to pay the same amount of money. On the other hand, the ability-to-pay principle suggests that water payments should be linked to income levels. This partially explains the great variety of mechanisms aimed at tackling equity and affordability issues in water supply.

In practice, countries employ different approaches to achieve equity aims: incomesupport policies (money transfers) and tariff-related policies (special tariffs). Since there is no consensus about the desirability of using prices to achieve redistributive goals and foster the ability-to-pay principle, income-support tools emerge as a less distortionary option (Bös, 1985; OECD, 1987; le Blanc, 2008; Schoengold and Zilberman, 2014; Soto et al., 2018). Figure 1 summarizes both kinds of policy approach.

Figure 1. Mechanisms to ensure equity and affordability in the water sector

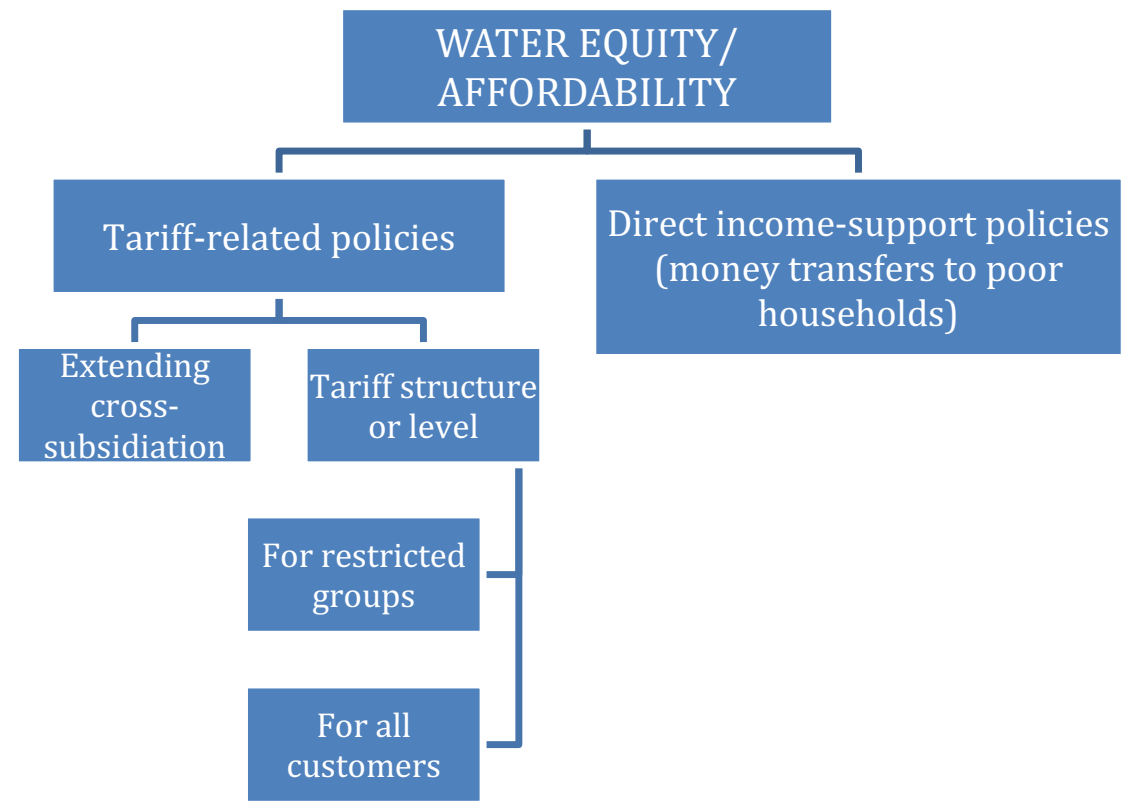

Adapted from OECD (2003)

When attempting to solve consumers' affordability problems, income-support policies are commonly applied. The OECD (2003, pp.54-55) describes different initiatives in this context, which lead to "absolute-value water bill reductions or waivers that became known before or well after the act of consumption (...)". Thus, low-income consumers may be eligible for direct income assistance or water service vouchers from the public sector, water utilities or other private or charitable sources; payment assistance in the form of easier payment plans or special loan 
facilities; and arrears forgiveness. Ex-post financial aids can help households, but there is sometimes a considerable delay in the application of such measures. This situation is far from ideal given that consumers risk their water supply being cut off or other adverse consequences.

Tariff-related initiatives consist of making changes to water pricing (level and structure) in order to reduce the amount of the typical water bill faced by low-income users. Such changes include subsidizing utility prices; designing special tariff structures to achieve crosssubsidization, whether this refers to low income households being cross-subsidized by nonresidential users or by the rest of residential sector; capping metered tariffs for low-income users; and/or designing special demand-management programmes that target low-income households. However, these measures entail significant trade-offs among equity and efficiency or costrecovery principles (OECD, 2003, 2010). Moreover, eligibility criteria may not be well designed (Gómez-Lobo et al., 2000), generating extremely complex tariff structures ${ }^{1}$. As shown in the Water tariffs in Spain section, other criteria apart from income could be supporting the existence of "social" tariffs.

Regarding efficiency, several tools are available to reduce water use. Figure 2 depicts these instruments, distinguishing between two sets of policies. On the one hand, the marketbased policies include some economic instruments that provide incentives to reduce water consumption. Among other tools, water prices and subsidies are frequently used to achieve this objective.

Through general water tariffs applied to all customers (using increasing block structures and/or setting higher price levels) it should be possible to ration consumption (Arbués and Barberán, 2012; Schoengold and Zilberman, 2014). Nevertheless there are two issues that can affect the tariffs' performance: on the one hand, the low price-elasticities for residential users that, in general, previous studies have estimated (Arbués et al., 2003; Reynaud, 2015; Romano et

\footnotetext{
${ }^{1}$ For example, in Murcia, a city located in the Southeast of Spain, there are eight different special tariffs (six for large households and two for low-income households).
} 
al., 2016; Reynaud and Romano, 2018); on the other hand, the possibility that users react to marginal or average price (Nauges and Whittington, 2017). Moreover, it should also be possible to design specific incentives for those consumers who make significant efforts to save water (García-Valiñas et al., 2010). Subsidy programmes oriented towards encouraging households to make water-saving choices are also classified in this category (García-Valiñas et al., 2015).

Figure 2. Mechanisms to ensure water-use efficiency.

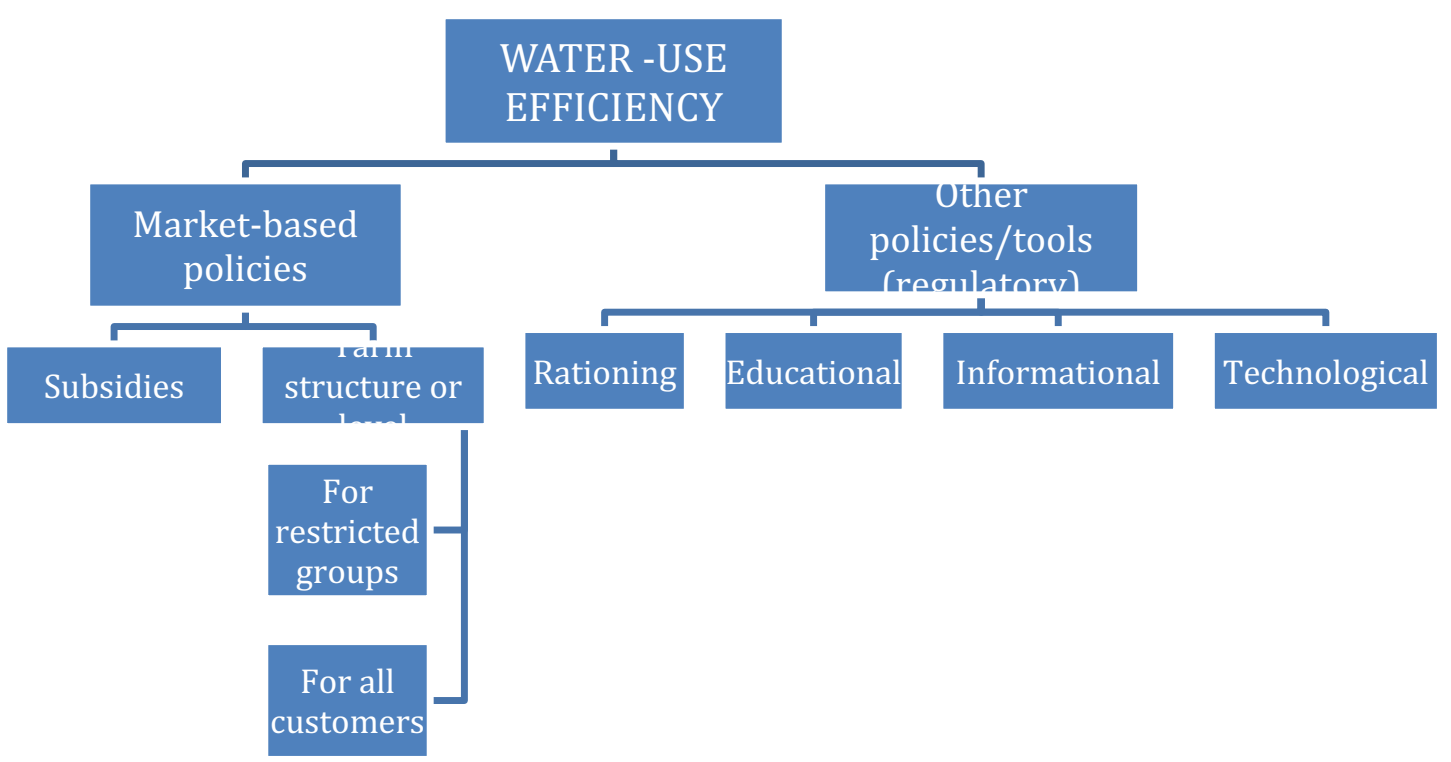

Authors' elaboration from García-Valiñas et al. (2015)

On the other hand, other policies, mainly regulatory, may be aimed at reducing water consumption. Alternative rationing policies could be implemented, setting quotas, banning the use of water to cover certain needs (watering gardens, washing cars, etc.) or even, when severe drought episodes occur, through cuts to the water supply2. Encouraging consumers to be aware of and/or responsible for water scarcity is another option to reduce water consumption (OECD, 1987; Randolph and Troy, 2008; Arbués et al., 2016). Regulation can also oblige water users to

\footnotetext{
2 Between 2017 and 2019 water cuts have been implemented as a policy tool in several urban areas of Andalucía, Extremadura, Galicia or Comunidad Valenciana. Those shortages are usually conducted when extreme scarcity situations happen, with the aim of quickly matching demand to available water supply.
} 
switch to using water-efficient appliances (OECD, 1987; Campbell et al., 2004; Lee and Tansel, 2013).

In any case, these measures aimed at reducing water consumption should be designed taking into account the cost recovery objective. Any measure that promotes a significative reduction of water consumption could hinder water suppliers from ensuring adequate funding. The result could be a decline of the level of service provided to the users, due to lack of maintenance and investment in water infrastructure.

In practice, water policies combine some of the aforementioned tools, and several public administrations and institutions are involved in their design. In any case, water prices are an essential element of water policies, since they are key to addressing both equity and efficiency issues in the water sector.

\section{Water Tariffs in Spain}

\section{General Features}

Urban water prices in Spain are among the lowest in the European Union (Arbués et al., 2017, OECD, 2010; 2013). Spain is a federal country where sub-central governments (regional and local) are autonomous entities with different responsibilities in the design of water policies. The extremely atomized local panorama and the strong power of the regional governments have led to a highly complex system with a wide range of water price levels and structures ${ }^{3}$.

In Spain, urban water supplies are served directly by public sector through local entities (municipal services, mancomunidades, consortium of municipalities or public companies) or indirectly by concession contract or delegating in public-private companies ${ }^{4}$. Table 1 shows how

\footnotetext{
3 The local government sector is made up of 50 provinces and 8,131 municipalities in 2019 (INE, 2019a). The regional government sector comprises 17 Autonomous Communities and 2 Autonomous Cities.

${ }^{4} \mathrm{~A}$ mancomunidad is an administrative form meant for purely inter-municipal cooperation helping to reach economies of scale in several local services such as water supply, solid waste collection, sewerage, recycling, etc. The mancomunidad is a management formula very common in rural areas with low population density. On the other hand, a supra-municipal consortium is a standing organization based on a vertical cooperation between municipalities and upper levels of government (regional or provincial) that
} 
water supply service is managed in the 15 largest Spanish cities, in which was registered around 23\% of the Spanish population in 2018 (INE, 2018a). In addition, these cities also have great relevance from the point of view of economic activity, given that $28 \%$ of Spanish enterprises are operating in those cities (INE, 2019b).

Table 1 Water management models in Spain

\begin{tabular}{|c|c|c|c|}
\hline City & Provision & Organizational form & Main characteristics \\
\hline Alicante & Indirect & Public-Private company & $\begin{array}{l}\text { 50\% public (municipality), 50\% private (Suez } \\
\text { Group) }\end{array}$ \\
\hline Barcelona & Indirect & Concession contract & $100 \%$ private (Suez Group) \\
\hline Bilbao & Direct & $\begin{array}{l}\text { Consortium of } \\
\text { municipalities }\end{array}$ & $\begin{array}{l}\text { 100\% public ( } 81 \text { municipalities, Diputación Foral de } \\
\text { Vizcaya) }\end{array}$ \\
\hline Córdoba & Direct & Public company & $100 \%$ public (municipality) \\
\hline Sevilla & Direct & Public company & $\begin{array}{l}11 \text { municipalities: Sevilla (69.36\%), Camas(2.50\%), } \\
\text { Alcalá de Guadaira(6.01\%), Coria del Río(2.46\%), } \\
\text { Dos Hermanas(10.79\%), La Rinconada(3.12\%), } \\
\text { Mairena del Alcor(1.74\%), San Juan de } \\
\text { Aznalfarache(1.98\%), Puebla del Río }(1,08 \%) \text {, Alcalá } \\
\text { del Río }(0,91 \%) \text { y El Garrobo (0,05\%). }\end{array}$ \\
\hline Gijón & Direct & Public company & $100 \%$ public (municipality) \\
\hline Madrid & Direct & Public company & $\begin{array}{l}\text { 100\% public: Regional Government (82.4\%), Madrid } \\
\text { City Council }(10 \%), 110 \text { municipalities }(7.67 \%)\end{array}$ \\
\hline Málaga & Direct & Public company & $100 \%$ public (municipality) \\
\hline Murcia & Indirect & Public-Private company & $\begin{array}{l}51 \% \text { public (municipality), } 49 \% \text { private (Suez } \\
\text { Group) }\end{array}$ \\
\hline $\begin{array}{l}\text { Palma de } \\
\text { Mallorca }\end{array}$ & Direct & Public & $100 \%$ public (municipality) \\
\hline $\begin{array}{l}\text { Las Palmas } \\
\text { de Gran } \\
\text { Canaria }\end{array}$ & ect & Public- & $\begin{array}{l}34 \% \text { public (municipality), } 66 \% \text { private }(33 \% \text { SACYR } \\
\text { Agua, } 33 \% \text { SAUR Group) }\end{array}$ \\
\hline Valencia & Indirect & Public-Private company & $\begin{array}{l}\text { 20\% public (municipality), } 80 \% \text { private (Global } \\
\text { Omnium) }\end{array}$ \\
\hline Valladolid & Direct & Public company & $100 \%$ public (municipality) \\
\hline Vigo & Indirect & Concession contract & $100 \%$ private (AQUALIA-FCC Vigo) \\
\hline Zaragoza & Direct & In-house provision & Municipal Services \\
\hline
\end{tabular}

Source: authors' calculations

Regardless of the management model chosen, local governments are responsible for providing water services in the urban sector, and setting the prices for those services ${ }^{5}$. Usually,

allows city councils to provide together water supply and sanitation services. The most important Spanish supra-municipal consortium in Spain is the Bilbao-Vizcaya Water Consortium which serves $91 \%$ of the population in the Vizcaya province.

5 Minimum services provided depend on the municipality size (in terms of population). Thus, all municipalities are obliged to provide water supply and sewage services, but only those with more than 50,000 inhabitants are obliged to treat wastewater, in the framework of environmental conservation policies. In the case of municipalities with fewer than 50,000 inhabitants, supra-municipal bodies usually provide these sanitation services. Moreover, local governments can also outsource the provision of those 
although the tariff structure is almost the same, local governments charge different prices for the water services provided: supply and sewerage. In most cities, wastewater treatment services are included in the sewerage tariff, although some cities establish a specific tariff for wastewater treatment (e.g. Sevilla or Valencia). Furthermore, regional governments in Spain are in charge of green taxation, designing specific charges on water consumption and/or pollution charges (Calatrava et al, 2015; García-Valiñas, 2019). These specific water taxes (usually applied to urban users) are added to the users' final water bill. Moreover, in most Spanish cities, the urban water tariffs for all the water services (supply, sewerage and wastewater treatment) distinguish between residential and non-residential users. Additionally, there are usually specific tariffs for different customer categories within both the residential and non-residential users (see Figure 3). In the case of non-residential users the sewerage and wastewater treatment tariffs include several pollution coefficients, which increase the water bill according to the characteristics of their discharges.

Figure 3. Urban water tariffs in Spain.

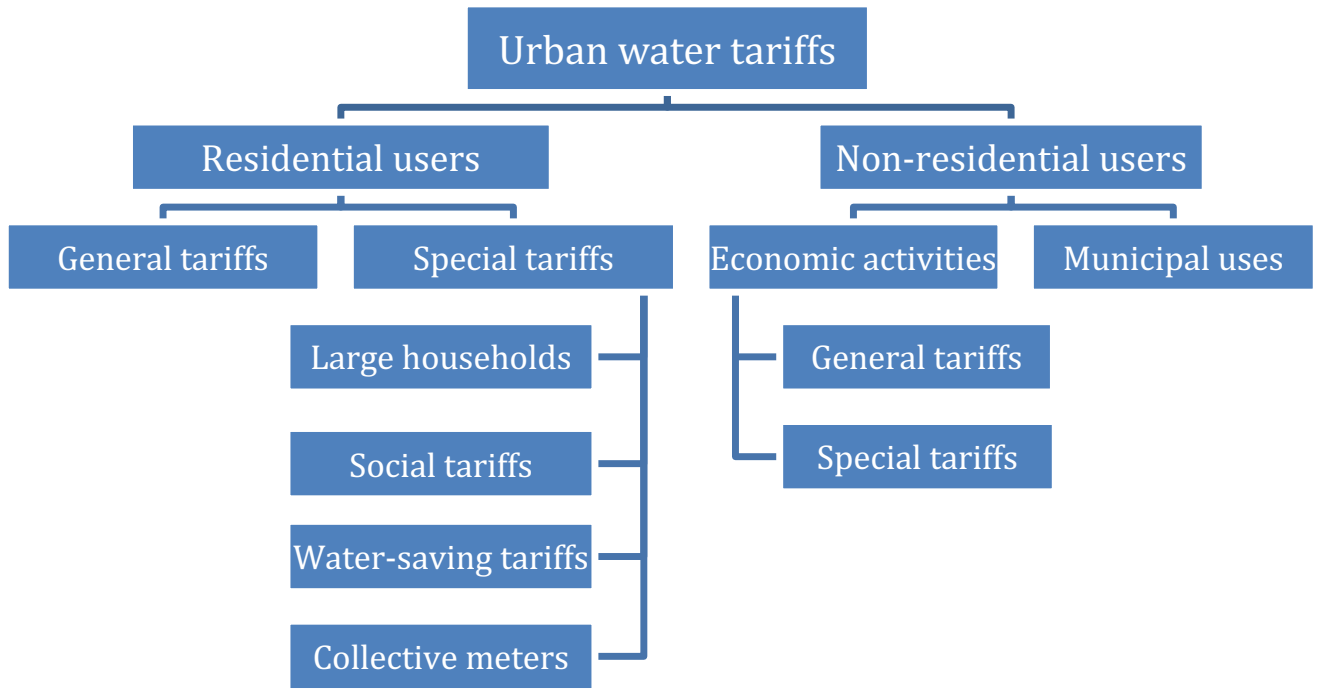

Authors' elaboration

services. Law 7/1985 on the Regulation of Local Government Terms and Conditions, Law 57/2003 on Local Government Modernization Measures, and Royal Decree 2/2000 establish the legal framework related to the provision of municipal services. 
As a result, the water-pricing map in Spain is enormously convoluted and involves several dimensions and elements. This feature of the system clearly contradicts the simplicity principle (OECD, 2003; 2010) required to ensure users' awareness of water price structure and level, and possibly make them more reactive to pricing policies. In the following subsections, this heterogeneity is illustrated with a description of the tariffs applied in the 15 largest Spanish cities. Moreover and since the complexity is huge, the description will exclusively cover the tariffs related to the supply water service in 2018 .

\section{Water Tariffs for Residential Users}

As mentioned in the General Features section, in most of the Spanish cities analysed there are two categories of residential water tariffs: a general tariff and special tariffs. In the case of the latter, households are eligible to apply for these tariffs if they meet certain specified criteria (relating to size, income, etc.). Water price structures are neither uniform nor linear, so charges include several elements and there is a high degree of heterogeneity across Spanish cities (Calatrava et al. 2015).

The General Tariff

The general tariff usually has a two-part structure, consisting of a fixed charge plus a variable charge. Although, theoretically, the fixed charge should be set to cover the costs of being connected to the public water network, it is actually a connection fee linked to the instantaneous water flow contracted. In most cases this connection fee is a tool to ensure that water services providers secure stable monthly revenues. This charge is usually calculated on the basis of the meter size ${ }^{6}$.

The volumetric charge is based on the volume of water consumed by each household. In most Spanish cities, water metered is billed on a monthly, bimonthly or quarterly basis depending

\footnotetext{
${ }^{6}$ There are some exceptions: for instance, in Córdoba, Jaén and Melilla the meter size criterion is combined with the type of the street set at the local business tax. In Mataró, the fixed charge does not depend on meter size, rather it is calculated on the basis of average metered consumption in the household for the previous 24 months.
} 
on the city ${ }^{7}$. Moreover, most cities use an Increasing Block Tariff (IBT) model to design their volumetric water charge ${ }^{8}$. Some Spanish cities located in different $\operatorname{areas}^{9}$, include free allowances or minimum-billed water use for basic levels of water consumption ${ }^{10}$. Additionally not all water cycle services are provided by the same organization. Different stages (supply, sewerage and wastewater treatment) can be managed by different institutions (public or private) according to different criteria. Thus, making comparisons based on the entire water bill could lead to confusion (Arbués et al., 2017). As a consequence, and since water supply represents a high percentage in the water bill (around 49\% according to Arbués et al., 2017), our study is exclusively related to the supply service. Table 2 presents a description of the volumetric charge for the water supply service applied in the 15 largest Spanish cities.

\footnotetext{
${ }^{7}$ In some cities, water bill period is four-month (e.g.: Guadalajara, Soria or Segovia), even biannual (e.g. Cáceres or Logroño).

${ }^{8}$ Seasonal tariffs offer an alternative structure for charging overconsumption. These structures are set in some Spanish cities (i.e. Alcalá de Henares). Moreover, some large cities (e.g. San Sebastián and Pamplona) apply a Uniform Volumetric Tariff (UVT) structure.

9 i.e., León (in the Northwest), Telde (in the Canary Islands) and Vigo (on the Atlantic Coast).

${ }^{10} \mathrm{~A}$ free allowance is a level of water consumption that is charged at zero marginal price. However, these free allowances have been criticized because they lead to significant efficiency losses. Users fail to reveal their preferences, since they do not face a marginal incentive to conserve water and usually consume more than they need (Castro et al., 2002). Additionally, a high degree of heterogeneity can be observed in the size of the free allowances. This suggests that no equity criterion is applied when setting this minimum amount of water. In fact, there is a clear trend of rejecting such instruments, because they are not environmentally efficient (they generate overconsumption) and show lower levels of equity than expected (OECD, 2003; 2010). Another frequent variation of the "free" allowance even more distorting is the minimum-billed water consumption (minimum water threshold charged), since users could be paying more water that they consume, leading to overconsumption.
} 
Table 2. Residential water tariff structure: volumetric charge

\begin{tabular}{|c|c|c|c|c|c|c|c|c|}
\hline City & $\begin{array}{l}\text { Billing } \\
\text { period }\end{array}$ & $\begin{array}{c}\text { Type of } \\
\text { tariff }\end{array}$ & $\begin{array}{c}\text { Number } \\
\text { of blocks } 1\end{array}$ & $\begin{array}{c}\text { First block } \\
\text { size } \\
\left(\mathrm{m}^{3} / \text { month) }\right.\end{array}$ & $\begin{array}{c}\text { Last block: } \\
\text { Kink point } \\
\left(\mathrm{m}^{3} / \text { month) }\right.\end{array}$ & $\begin{array}{c}\text { First block } \\
\text { price, } p_{\text {first }} \\
\left(€ / \mathbf{m}^{3}\right)\end{array}$ & $\begin{array}{l}\text { Last block } \\
\text { price, plast } \\
\left(€ / \mathbf{m}^{3}\right)\end{array}$ & $\begin{array}{c}\text { Ratio } \\
\left(p_{\text {last }} / \mathbf{p}_{\text {first }}\right)\end{array}$ \\
\hline Alicante & Quarterly & IBT & 4 & 4.00 & 21.00 & 0.01 & 2.56 & 256.00 \\
\hline Barcelona & Monthly & IBT & 5 & 7.00 & 18.00 & 0.61 & 3.04 & 5.00 \\
\hline Bilbao & Quarterly & IBT & 3 & 8.33 & 25.00 & 0.57 & 1.25 & 2.20 \\
\hline Córdoba & Bimonthly & IBT & 3 & 9.00 & 18.00 & 0.79 & 1.23 & 1.55 \\
\hline Gijón & Bimonthly & IBT & 3 & 15.00 & 25.00 & 0.38 & 0.71 & 1.88 \\
\hline $\begin{array}{l}\text { Las Palmas de } \\
\text { Gran Canaria }\end{array}$ & Bimonthly & IBT & 3 & 5.00 & 14.00 & 1.21 & 3.17 & 2.62 \\
\hline Madrid & Bimonthly & IBT & 3 & 12.50 & 25.00 & 0.13 & 0.50 & 3.76 \\
\hline Málaga & Monthly & IBT & 4 & 2.00 & 5.00 & 0.21 & 1.41 & 6.76 \\
\hline Murcia $^{2}$ & Bimonthly & IBT & 5 & 3.00 & 45.00 & 0.99 & 2.64 & 2.67 \\
\hline $\begin{array}{l}\text { Palma de } \\
\text { Mallorca }\end{array}$ & Bimonthly & IBT & 5 & 5.00 & 40.00 & 0.60 & 5.76 & 9.60 \\
\hline Sevilla & Monthly & IBT & 3 & 4.00 & 5.00 & 0.50 & 1.61 & 3.22 \\
\hline Valencia & Bimonthly & IBT & 2 & 6.00 & 6.00 & 0.47 & 0.55 & 1.17 \\
\hline Valladolid & Quarterly & IBT & 5 & 5.33 & 15.00 & 0.27 & 0.66 & 2.45 \\
\hline Vigo & Bimonthly & $\mathrm{IBT}+\mathrm{MB}$ & $5+1$ & 15.00 & 100.00 & 0.39 & 1.17 & 3.03 \\
\hline Zaragoza & Quarterly & IBT & 3 & 6.00 & 18.48 & 0.21 & 1.26 & 5.99 \\
\hline
\end{tabular}

Note: For simplicity, all figures are reported with two decimals

Legend: IBT: Increasing block tariff; MB: Minimum-billed water consumption

${ }^{1}$ Where there is a MB or free allowance, this is shown separately (e.g. 2+1)

${ }^{2}$ The size of the blocks varies according to the diameter of the meter. In this table a $13 \mathrm{~mm}$ diameter water meter is considered.

Source: authors' calculations

Table 2 shows that the IBT structure differs widely among cities. These differences are especially significant in the block size (the first block ranges from $2 \mathrm{~m}^{3} / \mathrm{month}$ in Málaga to 15.00 $\mathrm{m}^{3}$ /month in Gijón or Vigo). Moreover, the monthly consumption level at which the last block starts ranges from $5 \mathrm{~m}^{3} /$ month in Sevilla to $100 \mathrm{~m}^{3} / \mathrm{month}$ in Vigo. Additionally, broad variations in prices are also registered (the price of the first block ranges from $0.01 € / \mathrm{m}^{3}$ in Alicante to 1.21 $€ / \mathrm{m}^{3}$ in Las Palmas de Gran Canaria, while the price of last block ranges from $0.5016 € / \mathrm{m}^{3}$ in Madrid to $5.76 € / \mathrm{m}^{3}$ in Palma de Mallorca) ${ }^{11}$.

\footnotetext{
${ }^{11}$ Regarding the link between price levels and type of water services management, no clear results have been found in Spain. García-Valiñas et al. (2010), based on a sample of municipalities located in Southern Spain, found that private suppliers set higher price levels for a minimum water consumption threshold. Moreover, García-Valiñas et al. (2013) detected lower price levels under in-house public provision.
} 
As discussed in the previous section, the main objective of IBTs in Spain is to promote the efficient use of water by households, penalizing "excessive" consumption ${ }^{12}$. They are highly recommended by international institutions, such as the World Bank or the OECD, as useful tools for achieving efficiency and equity aims (OECD, 2010, 2015; Rogers et al., 2002). Nevertheless there is an increasing consensus about IBTs not being an effective measure to accomplish these objectives, especially if households respond to marginal prices and the correlation between income and water use is low (Andres et al., 2019; Nauges and Whittington, 2017).

The last column of Table 2 shows that the ratio of the last block price to the first block price registers a value higher than or equal to 3 in many cases, reflecting a heavy surcharge for the highest consumption levels. Most notably, in Alicante the price in the last block is 256 times the price in the first block. On the other hand, there are some cities such as Córdoba and Valencia where the ratio is close to one; therefore, the penalty applied is low when consumption is registered in the last block.

Special Tariffs for Large Households

As indicated in The General Tariff section, cities implement IBTs to discourage the excessive use of water. However, water consumption and household size are directly related (Arbués et al., 2003; Arbués et al., 2010) and the application of IBTs adversely affects large households. From the perspective of equity, water tariffs should fulfil the benefit principle, which establishes that, for the same quantity and quality of water supplied, different users should pay the same amount of money. Nevertheless, non-corrected IBTs lead to higher per-capita payments for large households. For this reason, most Spanish cities have introduced special tariffs attempting to partially mitigate these negative effects.

However, Arbués et al. (2017) found that the management model (direct or indirect) of water services appears as irrelevant in big and medium-size Spanish cities.

12 The level of water consumption meant by "excessive" is not defined according to any objective criterion. 
Generally speaking, these special tariffs entail the design of a new IBT where one or several components of the general tariff are changed. As shown in Table 3, the most common option consists of extending the size of the blocks, while maintaining the prices of the general tariffs (Alicante, Barcelona, Murcia, Las Palmas de Gran Canaria, Sevilla and Zaragoza), or combining the extension with a price change (Madrid, Málaga, Palma de Mallorca and Valencia). In Bilbao, the IBT has been replaced by a Uniform Volumetric Tariff (UVT). Córdoba and Valladolid have opted to change only the general tariff prices. Finally, Palma de Mallorca and Valladolid have established a discount on the fixed charge of $15 \%$ and $50 \%$, respectively.

In most of the cities analysed, special tariffs are set according to household size, since large households may vary in size. Conversely, in Bilbao, Córdoba, Las Palmas de Gran Canaria, Palma de Mallorca and Valladolid the special tariff is the same for all large households regardless of size, which probably means that the largest households continue to suffer from the adverse effects of IBTs. 
Table 3. Special tariffs for large households in large Spanish cities

\begin{tabular}{|c|c|c|c|c|c|c|c|}
\hline \multirow[b]{2}{*}{ City } & \multirow[b]{2}{*}{$\begin{array}{l}\text { Average family } \\
\text { size }\end{array}$} & \multirow[b]{2}{*}{ Eligibility conditions } & \multicolumn{4}{|c|}{ Changes relative to the general tariff } & \multirow{2}{*}{$\begin{array}{l}\text { Is the special } \\
\text { tariff the same } \\
\text { for all family } \\
\text { sizes? }\end{array}$} \\
\hline & & & $\begin{array}{c}\text { Discounts } \\
\text { on the fixed } \\
\text { charge }\end{array}$ & $\begin{array}{c}\text { Block } \\
\text { extension }\end{array}$ & $\begin{array}{l}\text { Change in } \\
\text { prices }\end{array}$ & $\begin{array}{c}\text { Change in } \\
\text { prices and } \\
\text { blocks }\end{array}$ & \\
\hline Alicante & 2.57 & $\begin{array}{l}\text { Accredited large families with } 3 \text { or more } \\
\text { children. }\end{array}$ & & $x$ & & & No \\
\hline Barcelona & 2.43 & Households with 4 or more people ${ }^{a}$ & & $\mathrm{x}$ & & & No \\
\hline Bilbao & 2.41 & Accredited large families & & & & UVT & Yes \\
\hline Córdoba & 2.71 & Accredited large families & & & $x$ & & Yes \\
\hline Gijón & 2.29 & - & - & - & - & - & - \\
\hline $\begin{array}{l}\text { Las Palmas de } \\
\text { Gran Canaria }\end{array}$ & 2.75 & Households with 4 or more people & & $\mathrm{x}$ & & & Yes \\
\hline Madrid & 2.52 & $\begin{array}{l}\text { Accredited large and extra-large families } \\
\text { and households with } 5 \text { or more people. }\end{array}$ & & & & $\mathrm{x}$ & No \\
\hline Málaga & 2.72 & All households ${ }^{b}$ & & & & $x$ & No \\
\hline Murcia & 2.88 & Households with 4 or more people & & $x$ & & & No \\
\hline Palma de Mallorca & 2.82 & Accredited large families & $x$ & & & $x$ & Yes \\
\hline Sevilla & 2.65 & All households ${ }^{b}$ & & $x$ & & & No \\
\hline Valencia & 2.52 & Accredited large and extra-large families & & & & $\mathrm{x}$ & No \\
\hline Valladolid & 2.41 & Accredited large families & $x$ & & $x$ & & Yes \\
\hline Vigo & 2.69 & - & - & - & - & - & - \\
\hline Zaragoza & 2.57 & Households with 6 or more people & & $x$ & & & No \\
\hline
\end{tabular}

Legend: UVT: Uniform Volumetric Tariff

${ }^{a}$ According to Catalonian Social Services, a person with a disability level greater than or equal to $75 \%$ or with a high level of dependence (he/she needs assistance with most daily activities, several times a day) counts as two people.

${ }^{\text {b }}$ Per-head IBT. Applicable if household's members are officially registered as residents in the dwelling.

Source: authors' calculations 
A relevant issue of these special tariffs is related to the requirements established in the municipal regulations to be able to benefit from those tariffs. First of all, it is striking that the eligibility criteria vary substantially across the cities, and the definition of "large household" may be different depending on the household's place of residence. Accredited large families (families with 3 or 4 children) and accredited extra-large families (families with 5 or more children) are usually eligible to apply for the special tariffs. However, the number of members required for a household to be categorized as eligible ranges from any size (i.e. Sevilla or Málaga) to 6 members (Zaragoza). Moreover, the number does not appear to be clearly correlated with the average family size in the municipality. These features of the system give rise to some unequal situations across different territories/areas. Second, in several cities such as Alicante, Bilbao, Córdoba, Palma de Mallorca, Valencia and Valladolid, the special tariff is only available to households who meet certain legal requirements (the aforementioned large family certification) ${ }^{13}$. As a consequence, large households that do not hold this status suffer from arbitrary discrimination. Finally, note that the utility does not have information about the family/household size, so households complying with the eligibility criteria in each case should apply for the application of these special tariffs. So, there could be some entitled households not being aware of these discounts and, as a consequence not benefiting from them.

Summarizing, these special tariffs represent an attempt to solve an equity problem associated with the general rate structure. In order to determine the effects generated by the special tariffs, the methodology proposed by Arbués and Barberán (2012) based on

\footnotetext{
${ }^{13}$ In Spain, different types of accredited large families are defined in the Law 40/2003 of 18 November, on Protection of Large Families (BOE, 2003). This law indicates that families which meet the following criteria, and make the request, are accredited as large families: 1.- Families with five or more members, with two parents and three or more minor children of less than 21 years old (or less than 25 years old if they are students); 2.- Families with four members with one parent and three children (or two parents and two children if one of the latter is physically or psychologically handicapped); 3.- Families of three members with one parent and two children, if one of the children is handicapped. Furthermore, families with five or more children or with four children if two or more are from a multiple birth (or multiple adoption) are accredited as special large families.
} 
three headcount indices and a targeting performance index is followed. As those authors point out, these measures allow observing whether special water tariffs are appropriate for large families.

As detailed public information on water consumption by household size in each city is not available, the calculation of these indices is based on simulating the variable charge for each household size. Thus, representative water consumption for a three-person household is estimated using the household water consumption in the autonomous community (INE, 2018b). Subsequently the standard consumption for each household size was obtained using the average elasticity of consumption with respect to household size obtained by Arbués et al. (2004)14.

The headcount indices indicate how many people living in households of different sizes benefit from the tariff 15 . To this end, it is necessary establish the price threshold below which a household benefits from the tariff. Following the equity criteria proposed by Arbués and Barberán (2012), this threshold should be calculated in each city as follows:

$$
p^{*}=\frac{\text { Total revenues if the general tariff is applied }}{\text { Total population }}
$$

Thus, $p^{*}$ is the price level that make the variable charge per capita equal for all households regardless of their size. We assume that a household benefits or is getting subsidized from the tariff if the price that household pays is lower than $p^{*}$.

Table 4 displays the calculations of three headcount indices for the 15 largest Spanish cities:

a) General Headcount Index (GHI). It shows the percentage of people in the population that benefits in some way when applying a tariff (general or special).

\footnotetext{
14 The average value of the elasticity of consumption with respect household size was estimated by (Arbués et al. 2004) at 0.8097 . This result implies that household water consumption varies $0.898 \%$ when household size increases $1 \%$.

${ }^{15}$ Data about total population and people living in households are obtained from INE (2013).
} 


$$
G H I=\frac{\text { People with } p<p^{*}}{\text { Total population }}
$$

b) Small Household Headcount Index ( $\left.\mathrm{HHI}_{\mathrm{S}}\right)$. It indicates the \% of people living in households with 3 members or fewer that benefit from a tariff.

$$
H H I_{S}=\frac{\text { People living in households with } 3 \text { members or fewer paying } p<p^{*}}{\text { People living in households with } 3 \text { members or fewer }}
$$

c) Large Household Headcount Index $\left(\mathrm{HHI}_{\mathrm{L}}\right)$. It indicates the \% of people living in households with four or more members that benefit from a tariff .

$$
H H I_{L}=\frac{\text { People living in households with } 4 \text { members or more paying } p<p^{*}}{\text { People living in households with } 4 \text { members or more }}
$$

Table 4. General and special tariffs headcount indices

\begin{tabular}{lcccccc}
\hline City & \multicolumn{3}{c}{ Under the general tariff } & \multicolumn{3}{c}{ After introducing special tariffs } \\
\cline { 2 - 7 } & GHI & HHI $_{\mathbf{S}}$ & $\mathbf{H H I}_{\mathbf{L}}$ & $\mathbf{G H I}$ & HHI $_{\mathbf{S}}$ & HHI $_{\mathbf{L}}$ \\
\hline Alicante & 0.35 & 0.59 & 0.00 & 0.35 & 0.59 & 0.00 \\
Barcelona & 0.65 & 1.00 & 0.00 & 0.35 & 0.00 & 1.00 \\
Bilbao & 0.61 & 0.41 & 1.00 & 0.61 & 0.41 & 1.00 \\
Córdoba & 0.92 & 0.85 & 1.00 & 0.12 & 0.00 & 0.25 \\
Gijón & 0.56 & 0.41 & 1.00 & - & - & - \\
Madrid & 0.49 & 0.38 & 0.65 & 0.38 & 0.38 & 0.36 \\
Málaga & 0.29 & 0.55 & 0.00 & 0.70 & 0.44 & 1.00 \\
Murcia & 0.92 & 0.85 & 1.00 & 0.42 & 0.46 & 0.38 \\
Palma de Mallorca & 0.59 & 1.00 & 0.00 & 0.64 & 1.00 & 0.13 \\
Las Palmas de Gran & 0.56 & 1.00 & 0.00 & 0.58 & 1.00 & 0.04 \\
Canaria & 0.31 & 0.56 & 0.00 & 0.69 & 0.44 & 1.00 \\
Sevilla & 0.63 & 0.41 & 1.00 & 0.63 & 0.41 & 1.00 \\
Valencia & 0.39 & 0.60 & 0.00 & 0.39 & 0.60 & 0.00 \\
Valladolid & 0.67 & 0.45 & 1.00 & - & - & - \\
Vigo & 0.37 & 0.59 & 0.00 & 0.37 & 0.5880 & 0.00 \\
Zaragoza & & & & & & \\
\hline
\end{tabular}

Source: authors' calculations

In the first column of Table 4, the GHI index shows the existence of benefits among different-sized households in all cities when the general tariff is applied. In some cities, such as Córdoba and Murcia, a high percentage of people benefit from general tariff (above 
90\%). ${ }^{16}$ The comparison between $\mathrm{HHI}_{\mathrm{S}}$ and $\mathrm{HHI}_{\mathrm{L}}$ under the general tariff shows that in six cities it is the large households that benefit the most from general tariffs (Bilbao, Córdoba, Gijón, Murcia, Valencia and Vigo). Nevertheless, it is noteworthy that in all cities a significant percentage of small households benefit from implicit subsidies in the general tariff.

Comparing these results with the three last columns it is observed that after the application of special tariffs, the results obtained vary widely across cities. Looking at the $\mathrm{HHI}_{\mathrm{L}}$, in some cities (i.e., Barcelona, Málaga and Sevilla) special tariffs lead to 100\% of large households being benefited. In other areas, the impact of special tariffs on large families is very small (e.g. in Mallorca or Las Palmas de Gran Canaria, where only $12.7 \%$ and $4.4 \%$ of large households are benefited, respectively). Indeed, in some cities, such as Córdoba, the special tariff eligibility requirements along with the amount of the benefits received by large families mean that the $\mathrm{HHI}_{\mathrm{L}}$ index is lower after the introduction of the special tariff. Finally, in other municipalities (i.e., Alicante, Valladolid and Zaragoza) large families do not experience a significant change after the introduction of special tariffs. This last finding suggests that, in those areas, large families continue to be net contributors.

Table 5 shows the calculations of the Targeting Performance Index $(\Omega)$ proposed by Komives et al. (2005). This index enables the evaluation of cross-subsidization among accredited large families and non-accredited large households. Following Komives et al. (2005) we calculate the index as follows:

$$
\Omega_{N}=\frac{\left({ }_{N} / P_{N}\right)}{\left(S_{T} / P_{T}\right)}
$$

where $S_{N}$ and $S_{T}$ indicate the implied benefit that people living in an N-sized household receive and the benefit the entire population as a group receives, respectively; $\mathrm{P}_{\mathrm{N}}$ is the

\footnotetext{
${ }^{16}$ Although there is a high percentage of people benefiting from general tariff, the average profit per capita is low ( $0.05 €$ in both cities).
} 
number of people living in $\mathrm{N}$-sized households; and $\mathrm{P}_{\mathrm{T}}$ is the number of inhabitants in the city ${ }^{17}$.

As Arbués and Barberán (2012) indicate, the larger $\Omega$, the higher the benefit obtained by N-sized households with respect to other households. In Table 5, we observe that in cities where the special tariff is exclusively applied to accredited large households, these households benefit much more than non-accredited households of the same size. Moreover, except in Córdoba, the larger the household, the higher the benefit (as the increasing trend of $\Omega$ shows). Only in Valladolid and Zaragoza, where the special tariff does not modify the previous status quo, does $\Omega$ remain constant.

In short, although general tariffs generate equity problems, large households are not always adversely affected. Moreover, these special tariffs help to redirect benefits between large and small households, but in some cases they simply add new privileges to those already existing. At this point, it is important to state that trying to address equity with respect to household size could have unexpected consequences depending on the correlation between household size and income.

Finally, the requirement of being accredited as a large family to access the special rate may excessively favour some large households to the detriment of the large households that do not fulfill the legal requirements to be qualified as large family and enjoy the benefits associated to this qualification (Law 40/2003, de Protección a las Familias Numerosas).

17 To obtain the amount of benefits received, the price threshold is the same as the one used to calculate the headcounts indices. 
Table 5. Targeting performance index: non-accredited vs. accredited large families

\begin{tabular}{|c|c|c|c|c|c|c|c|c|c|c|}
\hline \multirow{2}{*}{ City } & \multicolumn{5}{|c|}{ Households not accredited as large families } & \multicolumn{5}{|c|}{ Households accredited as large families } \\
\hline & $\Omega_{4}$ & $\Omega_{5}$ & $\mathbf{\Omega}_{6}$ & $\mathbf{\Omega}_{7}$ & $\Omega_{8}$ & $\mathbf{\Omega}_{4}$ & $\Omega_{5}$ & $\mathbf{\Omega}_{6}$ & $\mathbf{\Omega}_{7}$ & $\Omega_{8}$ \\
\hline Alicante & 0.00 & 0.00 & 0.00 & 0.00 & 0.00 & 0.00 & 0.00 & 0.00 & 0.00 & 0.00 \\
\hline Bilbao & 1.08 & 1.51 & 1.97 & 2.42 & 2.85 & 3.07 & 4.13 & 4.98 & 5.69 & 6.29 \\
\hline Córdoba & 0.00 & 0.09 & 0.00 & 0.00 & 0.00 & 19.09 & 18.84 & 15.17 & 12.74 & 11.05 \\
\hline Palma de Mallorca & 0.00 & 0.00 & 0.00 & 0.00 & 0.00 & 1.31 & 2.25 & 3.01 & 3.64 & 4.17 \\
\hline Valencia & 1.50 & 2.45 & 3.26 & 3.95 & 4.56 & 5.70 & 6.32 & 5.78 & 12.60 & 13.09 \\
\hline Valladolid & 0.00 & 0.00 & 0.00 & 0.00 & 0.00 & 0.00 & 0.00 & 0.00 & 0.00 & 0.00 \\
\hline
\end{tabular}

Legend: $\Omega_{\mathrm{N}}=0 \rightarrow \mathrm{N}$-sized households do not receive subsidies; $1>\Omega_{\mathrm{N}}>0 \rightarrow \mathrm{N}$-sized households receive subsidies but the benefit per capita they receive is lower than the benefit received by the remaining households; $\Omega_{\mathrm{N}}=1 \rightarrow \mathrm{N}$-sized households receive subsidies and the benefit per capita they receive is equal to the benefit received by the remaining households; $\Omega_{\mathrm{N}}>1 \rightarrow \mathrm{N}$-sized households receive a subsidy, and the benefit per capita is higher than the benefit received by the remaining households (Arbués and Barberán, 2012)

Source: authors' calculations 


\section{Social Tariffs}

Over the last decades, Spanish municipalities have systematically used water tariffs as a tool to improve the income distribution. As mentioned in the General Features section, this approach is in line with water pricing principles related to equity and affordability (OECD, 1987; 2003; 2010), recognizing water as a human right and a merit good. The public sector has promoted social tariffs in order to protect socially- and economically-vulnerable households who are more likely to fall into "water poverty"18. Table 6 displays the main characteristics of the social tariffs applied in the 15 largest Spanish cities. In most cases, the eligible vulnerable groups are low-income households, elderly people and households where all members are unemployed ${ }^{19}$.

With the aim of guaranteeing households have access to water services, most social tariffs apply a discount to the fixed charge. While this measure could be entirely justified for social reasons, it is misguided from an economic efficiency point of view. Thus, the fixed charge is intended to cover costs related to access to the service (pipes and other infrastructure), and there is no basis for expecting different access costs for different households living in the same area. Moreover, changes also are made to the volumetric charge in terms of reducing prices or extending the size of the blocks. This measure has a negative impact on efficiency and environmental aims, also creating cross-subsidization among different user groups.

\footnotetext{
18 Reynaud (2007) defines a "water-poor" household as a household spending $3 \%$ or more of its income on water services.

19 In some cities, the benefits are extended to other social groups such as those eligible to receive a widow's or widower's pensions (Madrid), disabled people (Huelva) or women who have been the victims of gender-based violence (i.e., Huelva and Elche).
} 
Table 6. Social tariffs in large Spanish cities

\begin{tabular}{|c|c|c|c|c|c|}
\hline \multirow[t]{2}{*}{ City } & \multirow[t]{2}{*}{ Eligibility criteria } & \multicolumn{4}{|c|}{ Changes relative to the general tariff } \\
\hline & & $\begin{array}{l}\text { Fixed } \\
\text { charge }\end{array}$ & Blocks & Prices & $\begin{array}{l}\text { Prices } \\
\text { and } \\
\text { blocks }\end{array}$ \\
\hline Alicante & - & - & - & - & - \\
\hline Barcelona & $\begin{array}{l}\text { People over } 60 \text { years old; People who receive a basic pension (retirement, } \\
\text { widow/widower or disability); Families where all members are unemployed }\end{array}$ & $\mathrm{x}$ & & $\mathrm{x}$ & \\
\hline Bilbao & $\begin{array}{l}\text { People over } 60 \text { years old; People who receive a basic pension (widow/widower or } \\
\text { disability); Families where all members are unemployed }\end{array}$ & & & & $\mathrm{x}$ \\
\hline \multirow[t]{3}{*}{ Córdoba } & $\begin{array}{l}\text { Retired people and people who receive a pension with a monthly income lower than } \\
1.5^{*} \text { IPREM }\end{array}$ & & & $\mathrm{x}$ & \\
\hline & $\begin{array}{l}\text { Families where all members are unemployed or some are participating in the "Plan } \\
\text { Prepara" with an income lower than } 1.5^{*} \text { IPREM }\end{array}$ & & & $\mathrm{x}$ & \\
\hline & $\begin{array}{l}\text { Families at risk of social exclusion: income lower than (IPREM }+0.1 * \text { IPREM*(Adults- } \\
\text { 1) }+0.2^{*} \text { IPREM } * \text { Children) }\end{array}$ & & & & $\mathrm{x}$ \\
\hline Gijón & - & - & - & - & - \\
\hline $\begin{array}{l}\text { Las Palmas de Gran } \\
\text { Canaria }\end{array}$ & - & - & - & - & - \\
\hline \multirow[t]{2}{*}{ Madrid } & $\begin{array}{l}\text { Families at risk of social exclusion (evaluated by local social services on a case-by-case } \\
\text { basis) }\end{array}$ & $\mathrm{x}$ & & $\mathrm{x}$ & \\
\hline & $\begin{array}{l}\text { People who receive a widow's/widower's pension with a gross income lower than } \\
€ 14,000 / \text { year }\end{array}$ & $\mathrm{x}$ & & & \\
\hline
\end{tabular}


Table 6. Social tariffs in large Spanish cities (cont.)

\begin{tabular}{|c|c|c|c|c|c|}
\hline \multirow[t]{2}{*}{ City } & \multirow[t]{2}{*}{ Eligibility criteria } & \multicolumn{4}{|c|}{ Changes relative to the general tariff } \\
\hline & & $\begin{array}{l}\text { Fixed } \\
\text { charge }\end{array}$ & Blocks & Prices & $\begin{array}{c}\text { Prices } \\
\text { and } \\
\text { blocks }\end{array}$ \\
\hline Málaga & - & - & - & - & - \\
\hline \multirow[t]{2}{*}{ Murcia } & Retired people who receive a pension lower than the SMI & $\mathrm{x}$ & & & $\mathrm{x}$ \\
\hline & $\begin{array}{l}\text { Families at risk of social exclusion (evaluated by the local social services on a case-by- } \\
\text { case basis) with reduced water consumption (lower than } 110 \mathrm{l} / \mathrm{p} / \mathrm{d} \text { ) }\end{array}$ & & & & Flat rate \\
\hline Palma de Mallorca & Households with income lower than $€ 15,750 /$ year & $\mathrm{x}$ & & & $\mathrm{x}$ \\
\hline Sevilla & - & - & - & - & - \\
\hline Valencia & - & - & - & - & - \\
\hline Valladolid & People over 65 and people who receive a pension & $\mathrm{x}$ & & $\mathrm{x}$ & \\
\hline Vigo & - & - & - & - & - \\
\hline \multirow[t]{3}{*}{ Zaragoza $^{\text {a }}$} & Households with income lower than (SMI*1.123) if $\mathrm{N} \leq 4$ & $\mathrm{x}$ & & $\mathrm{x}$ & \\
\hline & Households with income between (SMI*1.5) and (SMI*1.66) if $\mathrm{N} \leq 5$ & & & $\mathrm{x}$ & \\
\hline & Households with income between $\left(1.123^{*} \mathrm{SMI}\right)$ and $\left(1.5^{*} \mathrm{SMI}\right)$ if $\mathrm{N} \leq 5$ & $\mathrm{x}$ & & $\mathrm{x}$ & \\
\hline
\end{tabular}

Legend: IPREM (Indicador Público de Efectos Múltiples): Official index used in Spain as a reference for granting financial assistance, allowances or unemployment benefits, among others. In 2019, IPREM was set at €537.84/month; The "Plan Prepara" is a public programme for unemployed people who do not receive any unemployment benefits. The beneficiaries of this programme receive financial assistance of €400/month; SMI (Salario Mínimo Interprofesional): Minimum wage. In 2019, SMI was set at €900/month.

a In Zaragoza, income thresholds are revisable in case of a household size enlargement.

Source: authors' calculations 
In order to examine the impact of the water rate on households, it can be useful to assess the relative effort required of households to pay for the water supplied. To that end, the following effort index (EI) is proposed:

$$
\mathrm{EI}=\frac{\text { Water bill }}{\text { Income }}
$$

with water bill being the amount paid by the average household that consumes the standard quantity of water in each city ${ }^{20}$. Since many of the social tariffs in place modify both the fixed and volumetric charges, both charges are included in the calculations. Table 7 shows the results of those calculations for the cities under analysisis ${ }^{21}$

Table 7. Effort index

\begin{tabular}{lccc}
\hline City & $\begin{array}{c}\text { Average } \\
\text { income }\end{array}$ & $\begin{array}{c}\mathbf{7 5 \%} \text { of } \\
\text { average } \\
\text { income }\end{array}$ & $\begin{array}{c}\mathbf{5 0 \%} \text { of } \\
\text { average } \\
\text { income }\end{array}$ \\
\hline Alicante & $0.82 \%$ & $1.09 \%$ & $1.64 \%$ \\
Barcelona & $0.72 \%$ & $0.96 \%$ & $1.44 \%$ \\
Bilbao & $0.27 \%$ & $0.36 \%$ & $0.53 \%$ \\
Córdoba & $0.62 \%$ & $0.83 \%$ & $1.23 \%$ \\
Gijón & $0.31 \%$ & $0.40 \%$ & $0.61 \%$ \\
Madrid & $0.09 \%$ & $0.13 \%$ & $0.19 \%$ \\
Málaga & $0.68 \%$ & $0.91 \%$ & $1.37 \%$ \\
Murcia & $0.91 \%$ & $1.20 \%$ & $1.81 \%$ \\
Palma de Mallorca & $0.55 \%$ & $0.73 \%$ & $1.09 \%$ \\
Las Palmas de Gran Canaria & $0.98 \%$ & $1.30 \%$ & $1.95 \%$ \\
Sevilla & $0.75 \%$ & $0.99 \%$ & $1.49 \%$ \\
Valencia & $0.42 \%$ & $0.56 \%$ & $0.84 \%$ \\
Valladolid & $0.24 \%$ & $0.33 \%$ & $0.48 \%$ \\
Vigo & $0.72 \%$ & $0.96 \%$ & $1.44 \%$ \\
Zaragoza & $0.25 \%$ & $0.33 \%$ & $0.50 \%$ \\
\hline Source: aus
\end{tabular}

Source: authors' calculations

As shown in Table 7, the relative economic effort required for an average-income household to pay for the water it consumes is low. In all cities, the EI value for average

20 Standard consumption was calculated using data from the 2008 Survey on Water Supply and Sewerage (INE, 2018b). It includes household water consumption by Autonomous Community, which has been used to obtain the average consumption for a 3-person household.

${ }^{21}$ Figures include exclusively water supply service charges. 
household income is below 1. For households whose income level is $75 \%$ of the average income, the EI remains relatively low. Finally, households with an income level of $50 \%$ of the average income do not record high EI values.

To improve our understanding of this subject, Table 8 presents the relative efforts made by households to have access to the water supply service, under both general and social tariffs. The income caps set in each social tariff are considered in the calculations as follows:

$$
\mathrm{EI}^{\prime}=\frac{\text { Water bill }}{\text { Maximum income level to benef it from social tariff }}
$$

Table 8. Effort index for general and social tariffs

\begin{tabular}{|c|c|c|c|c|}
\hline City & Groups (if more than one) & $\begin{array}{l}\text { Income level } \\
(€ / \text { month })^{\mathrm{a}}\end{array}$ & $\begin{array}{c}\text { General } \\
\text { tariff }\end{array}$ & $\begin{array}{l}\text { Social } \\
\text { tariffs }\end{array}$ \\
\hline Barcelona & & 836 & $2.62 \%$ & $2.14 \%$ \\
\hline Bilbao & & 836 & $0.91 \%$ & $0.89 \%$ \\
\hline \multirow[t]{3}{*}{ Córdoba } & $\begin{array}{l}\text { - Retired people and low- } \\
\text { income households }\end{array}$ & 807 & $1.74 \%$ & $1.11 \%$ \\
\hline & - Unemployed households & 807 & $1.74 \%$ & $1.11 \%$ \\
\hline & $\begin{array}{l}\text { - Families at risk of social } \\
\text { exclusion }\end{array}$ & 699 & $2.01 \%$ & $0.89 \%$ \\
\hline \multirow[t]{2}{*}{ Madrid } & $\begin{array}{l}\text { - Families at risk of social } \\
\text { exclusion }\end{array}$ & 430 & $0.74 \%$ & $0.19 \%$ \\
\hline & $\begin{array}{l}\text { - People who receive a } \\
\text { widow(er)'s pension }\end{array}$ & 1,17 & $0.27 \%$ & $0.20 \%$ \\
\hline \multirow[t]{2}{*}{ Murcia } & - Retired people & 900 & $2.43 \%$ & $1.16 \%$ \\
\hline & $\begin{array}{l}\text { - Families at risk of social } \\
\text { exclusion }\end{array}$ & 430 & $5.09 \%$ & $1.77 \%$ \\
\hline Palma de Mallorca & & 1,31 & $1.12 \%$ & $0.22 \%$ \\
\hline Valladolid & & 1,58 & $0.39 \%$ & $0.34 \%$ \\
\hline \multirow[t]{3}{*}{ Zaragoza } & $\begin{array}{l}\text {-Households with income } \\
\text { lower than (SMI*1.123) if } \mathrm{N} \leq 4\end{array}$ & 1,01 & $0.64 \%$ & $0.30 \%$ \\
\hline & $\begin{array}{l}\text {-Households with income } \\
\text { between (SMI*1.5) and } \\
\left(S^{*} 1.66\right) \text { if } \mathrm{N} \leq 5\end{array}$ & 1,49 & $0.43 \%$ & $0.42 \%$ \\
\hline & $\begin{array}{l}\text { Households with income } \\
\text { between }\left(1.123^{*} \mathrm{SMI}\right) \text { and } \\
\left(1.5^{*} \mathrm{SMI}\right) \text { if } \mathrm{N} \leq 5\end{array}$ & 1,35 & $0.48 \%$ & $0.33 \%$ \\
\hline
\end{tabular}

As can be seen in Table 8, there are no marked differences between the EI values under general and social tariffs, so the benefit is relatively low. The differences are significant in only two cities: in Córdoba, families at risk of social exclusion clearly benefit 
from the application of social tariffs; moreover, in Murcia, the reduction in EI values for households at risk of social exclusion is large, declining from $5.1 \%$ to $1.8 \%$.

Finally, it is worth noting that, quite apart from the expected effect of social tariffs, the stringent eligibility criteria mean that only a small percentage of households can benefit from those discounts. In short, social tariffs, in addition to running counter to some basic pricing principles (efficiency, environmental and cost-recovery issues), also violate the simplicity principle, generating extra administrative costs that have to be borne by all users. All of this reinforces the idea that other tools should be used to guarantee access to the water supply.

Although this social tariffs approach is the preferred option in many Spanish cities, incorporating redistributive elements into water tariffs does not appear to be a good choice. The design of a general grant system managed by social services ${ }^{22}$ emerges as a more appropriate option. Indeed this option is applied in Gijón and Vigo, where social tariffs have not been implemented. This alternative system has even been adopted in some municipalities where there are social tariffs in place (i.e. Bilbao or Valladolid) ${ }^{23}$. These systems are social assistance schemes that provide social transfers, usually in-kind, targeted at the poor households. This means that social services pay the bill of several basic services (water, electricity or gas) of these households.

\section{Collective Meters}

In some Spanish cities, a significant percentage of residential buildings are equipped with a collective water meter, instead of a series of individual meters. The water use registered by the collective meter is jointly paid for by all the residents in the housing block. Payments are commonly handled by the property manager, who divides the collective water bill

\footnotetext{
22 In Alicante, the transfers system has been implemented through several non-governmental
} organizations. 
among the households, usually based on the size of the apartment/dwelling. Although collective meters are gradually being replaced by individual meters in each dwelling-in order to be able to measure individual usage and charge for water used on the basis of the volume of water used by each household - there are still a lot of buildings that rely on these collective meters. ${ }^{24}$ Moreover, if no adjustments are applied, note that, under a IBT structure, the average price paid by the building increases with the number of apartments in the building.

${ }^{24}$ Currently, the individual units in newly-built residential buildings have to be equipped with individual water meters. Nevertheless, old buildings with collective meters do not have a legal obligation to change their water meter, except when the building is being renovated (e.g. in Barcelona). Thus, replacing collective meters with individual meters is a slow process that depends on the residents (owners) in each building. 
Table 9 .Tariffs for collective meters

\begin{tabular}{|c|c|c|}
\hline City & Fixed charge & Volumetric charge \\
\hline Alicante & General tariff & General tariff \\
\hline Barcelona & General tariff & General tariff \\
\hline Bilbao (I) & General tariff & General tariff \\
\hline Bilbao (II)b & $\begin{array}{l}\text { Number of dwellings*fixed charge for a } \\
15 \mathrm{~mm} \text { meter }\end{array}$ & $\begin{array}{l}\text { General tariff for (total } \\
\text { consumption /number of } \\
\text { dwellings) }\end{array}$ \\
\hline Córdoba & $\begin{array}{l}\text { The highest value between the fixed charge } \\
\text { at the general tariff and the number of } \\
\text { dwellings*fixed charge for a } 15 \mathrm{~mm} \text { meter }\end{array}$ & $\begin{array}{l}\text { General tariff with blocks } \\
\text { enlarged according to } \\
\text { number of dwellings }\end{array}$ \\
\hline Sevilla & $\begin{array}{l}\text { The highest value between the fixed charge } \\
\text { at the general tariff and the number of } \\
\text { dwellings*3.863€ }\end{array}$ & $\begin{array}{l}\text { General tariff with blocks } \\
\text { enlarged according to } \\
\text { number of dwellings }\end{array}$ \\
\hline Gijón & General tariff & IBT with 2 blocks \\
\hline Madrid & $\begin{array}{l}\text { Number of dwellings*fixed charge for a } \\
15 \mathrm{~mm} \text { meter }\end{array}$ & $\begin{array}{l}\text { General tariff with blocks } \\
\text { enlarged according to } \\
\text { number of dwellings }\end{array}$ \\
\hline Málaga & General tariff & UVT \\
\hline Murcia & General tariff & General tariff \\
\hline $\begin{array}{l}\text { Palma de } \\
\text { Mallorca }\end{array}$ & General tariff & UVT \\
\hline $\begin{array}{l}\text { Las Palmas de } \\
\text { Gran Canaria }\end{array}$ & (Number of dwellings*10.39)c & $\begin{array}{l}\text { General tariff with blocks } \\
\text { enlarged according to } \\
\text { number of dwellings }\end{array}$ \\
\hline Valencia & General tariff & General tariff \\
\hline Valladolid & General tariff & General tariff \\
\hline Vigo & General tariff & General tariff \\
\hline Zaragoza (I) ${ }^{d}$ & General tariff & $\begin{array}{l}\text { General tariff with blocks } \\
\text { enlarged according to } \\
\text { number of dwellings }{ }^{\mathrm{d}}\end{array}$ \\
\hline Zaragoza (II) ${ }^{\mathrm{e}}$ & General tariff & IBT with two blocks ${ }^{\mathrm{e}}$ \\
\hline
\end{tabular}

a This collective tariff is only for common hot water facilities.

b This collective tariff is only for common cold water facilities

c In Las Palmas, the fixed charge is only for collective meters with a consumption lower than or equal to (number of dwellings*10) and includes this consumption. In other cases, the fixed charge is 0 and all the consumption is paid according to the volumetric charge.

$\mathrm{d}$ This volumetric charge is for collective meters installed for residential uses in multi-apartment buildings.

e This volumetric charge is only for meters installed for common hot water facilities.

Source: authors' calculations

Frequently, the tariff applied to this collective consumption is the general tariff. However, in some cities, a specific tariff is applied. Table 9 describes these special tariffs relating to two dimensions: changes to the fixed charge and changes to the volumetric charge. The first entails adjusting the fixed charge according to certain criteria, such as the 
number of dwellings in the building (e.g. in Córdoba, Sevilla and Madrid). The second involves designing a new volumetric charge (e.g. in Gijón and Palma de Mallorca) or adjusting the blocks of the general tariff according to the number of dwellings connected to the collective meter (in Córdoba, Madrid and Zaragoza).

As shown in Table 10, these tariffs generate some distortions in terms of efficiency and equity. Looking at the left-hand side of the table, the fixed charge per dwelling is much lower (except in Palma de Mallorca) when it is calculated considering the diameter of the collective meter. However, the fixed charge is similar for individual and collective meters when a special tariff is set for the latter.

Table 10. Specific tariffs for collective meters vs. general tariff for individual meters

\begin{tabular}{|c|c|c|c|c|c|c|}
\hline \multirow[b]{3}{*}{ City } & \multicolumn{3}{|c|}{ Fixed cost per dwelling ( $€ /$ month) } & \multicolumn{3}{|c|}{$\begin{array}{l}\text { Volumetric charge (average price; } \\
\left.€ / \mathrm{m}^{3}\right)\end{array}$} \\
\hline & \multirow[b]{2}{*}{$\begin{array}{l}\text { Individual } \\
\text { meter } \\
(13 \mathrm{~mm} .)\end{array}$} & \multicolumn{2}{|c|}{ Collective meter (40mm.) } & \multirow[b]{2}{*}{$\begin{array}{l}\text { Individual } \\
\text { meter }\end{array}$} & \multicolumn{2}{|c|}{ Collective meter $(40 \mathrm{~mm})}$. \\
\hline & & $\begin{array}{c}\text { Multi- } \\
\text { apartment } \\
\text { building (10 } \\
\text { dwellings) }\end{array}$ & $\begin{array}{c}\text { Multi- } \\
\text { apartment } \\
\text { building ( } 25 \\
\text { dwellings) }\end{array}$ & & $\begin{array}{l}\text { Multi- } \\
\text { apartment } \\
\text { building (10 } \\
\text { dwellings) }\end{array}$ & $\begin{array}{c}\text { Multi- } \\
\text { apartment } \\
\text { building ( } 25 \\
\text { dwellings) }\end{array}$ \\
\hline Bilbao & 2.21 & 0.64 & 0.26 & 0.57 & 1.09 & 1.18 \\
\hline Córdoba & 3.90 & 5.66 & 3.87 & 0.85 & 0.85 & 0.85 \\
\hline Sevilla & 3.90 & 3.86 & 3.86 & 1.18 & 1.18 & 1.18 \\
\hline Gijón & 2.70 & 1.57 & 1.57 & 0.38 & 0.38 & 0.38 \\
\hline Madrid & 1.60 & 1.82 & 1.82 & 0.13 & 0.13 & 0.13 \\
\hline Málaga & 2.55 & 1.82 & 0.73 & 1.02 & 0.39 & 0.39 \\
\hline Palma de Mallorca & 4.60 & 36.78 & 14.71 & 0.84 & 0.93 & 0.93 \\
\hline $\begin{array}{l}\text { Las Palmas de Gran } \\
\text { Canaria }^{a}\end{array}$ & $5.20 / 0$ & $5.20 / 0$ & $5.20 / 0$ & 1.76 & 1.76 & 1.76 \\
\hline Zaragoza b & 2.30 & 4.45 & 1.78 & 0.35 & 0.35 & 0.35 \\
\hline & & & & & 1.15 & 1.21 \\
\hline
\end{tabular}

Note: Calculations based on the standard consumption for a 3-person household. For simplicity, all figures are reported with two decimals

a In Las Palmas de Gran Canaria, the fixed charge depends on water consumption. If consumption is lower than or equal to $10 \mathrm{~m}^{3} /$ month/dwelling the fixed charge is $€ 5.195 /$ month; If it exceeds $10 \mathrm{~m}^{3} /$ month/dwelling then the fixed charge is $€ 0 /$ month.

b In Zaragoza, the volumetric charge is different if collective consumption is for common hot water services (first row) or if is for other uses (second row).

Source: authors' calculations

Looking at the volumetric charge (right-hand side of Table 10), note that in most cities the average price per $\mathrm{m}^{3}$ is the same for all the dwellings. This is because, except in 
Gijón, the change to the volumetric charge consists of adapting the size of the blocks in the general tariff according to the number of dwellings connected to a collective meter. Nevertheless, this design can lead to equity problems if a number of dwellings connected to a collective meter are empty or if the individual units are of different sizes. In these cases, depending on the internal criteria for sharing the water bill among all the dwellings, some problems may arise in terms of efficiency (because the incentives to save water disappear, especially in the case of large households) and equity (cross-subsidies among dwellings connected to the same collective meter).

On the other hand, the two cities where the volumetric charge for collective meters is a UVT show different results. While in Málaga dwellings connected to a collective meter pay about $64 \%$ less per $\mathrm{m}^{3}$ than dwellings with an individual meter, in Palma de Mallorca a cubic meter is about $10 \%$ more expensive for collective meters than individual meters. Finally, in cities with a specific tariff for common hot water facilities (Bilbao and Zaragoza) the average price is substantially higher for collective meters.

\section{Efficient Water Use and Low Water Use Tariffs}

When looking at the 15 largest cities in Spain, only Zaragoza has special tariffs to specifically promote efficient water use, and Murcia, Palma de Mallorca and Sevilla have applied a special tariff to users registering low water consumption levels. However, extending the analysis to all Spanish cities with more than 100,000 inhabitants or provincial capitals $(79$ cities in total), additional examples of this kind of tariff can be found.

On the one hand, two cities (Teruel and Zaragoza) have a special tariff to encourage water savings. These special tariffs consist of a discount on the water price for households that reduce consumption relative to their previous consumption levels. Thus, in Teruel, a $55.6 \%$ discount on the fixed charge and a $10 \%$ discount on the volumetric charge of the general tariff is applied to households that achieve a $10 \%$ reduction in their annual consumption with respect to the previous year. In Zaragoza, households whose current 
consumption is at least $10 \%$ lower than that of the previous two years obtain a $10 \%$ discount on their volumetric charge. Furthermore, in another city (Terrassa) the fixed charge does not depends on the meter size and is made up of two parts: a general rate, which is the same for all households; and an individual rate, which depends on the household's previous consumption (the higher the consumption, the higher the individual rate).

On the other hand, there are seven cities that apply a special tariff to households whose water consumption is low (usually within the first block of the tariff); the requirements and the discounts are displayed in Table 11. Additionally, note that some of these special tariffs are applicable in combination with large households' tariffs or social tariffs.

Table 11. Low water consumption tariffs

\begin{tabular}{|c|c|c|c|c|}
\hline City & $\begin{array}{l}\text { Maximum consumption } \\
\text { allowed }\end{array}$ & Beneficiaries & Rate benefits & $\begin{array}{c}\text { Consumption } \\
\text { above maximum } \\
\text { allowed } \\
\end{array}$ \\
\hline Ciudad Real & $\begin{array}{l}12 \mathrm{~m}^{3} / \text { household/month } \\
7 \mathrm{~m}^{3} / \text { household/month }\end{array}$ & $\begin{array}{l}\text { Accredited } \\
\text { large families } \\
\text { Low income } \\
\text { households }\end{array}$ & $\begin{array}{l}4.97 \% \text { discount on } \\
\text { the fixed charge } \\
32.79 \% \text { discount on } \\
\text { the fixed charge }\end{array}$ & $\begin{array}{l}\text { No discount on } \\
\text { fixed charge }\end{array}$ \\
\hline $\begin{array}{l}\text { Dos } \\
\text { Hermanas } \\
\text { and Sevilla }\end{array}$ & $\begin{array}{l}\left(3^{*} \text { household size }\right) \\
\mathrm{m}^{3} / \text { month }\end{array}$ & $\begin{array}{l}\text { All households } \\
\text { that can prove } \\
\text { their size }\end{array}$ & $\begin{array}{l}26 \% \text { discount on } \\
\text { the first block price }\end{array}$ & $\begin{array}{l}\text { All consumption } \\
\text { is billed at the } \\
\text { general rate for } \\
\text { households that } \\
\text { prove their size }\end{array}$ \\
\hline $\begin{array}{l}\text { Jerez de la } \\
\text { Frontera }\end{array}$ & $7 \mathrm{~m}^{3} /$ household/month & All households & $\begin{array}{l}19.94 \% \text { discount } \\
\text { on the first block } \\
\text { price }\end{array}$ & $\begin{array}{l}\text { All consumption } \\
\text { is billed at the } \\
\text { general rate }\end{array}$ \\
\hline Murcia & $3.3 \mathrm{~m}^{3} /$ person $/$ month & $\begin{array}{l}\text { Families at } \\
\text { risk of social } \\
\text { exclusion }\end{array}$ & $\begin{array}{l}\text { Flat rate of } \\
€ 5 / \text { month }\end{array}$ & $\begin{array}{l}\text { Excess } \\
\text { consumption is } \\
\text { billed at the } \\
\text { general rate }\end{array}$ \\
\hline $\begin{array}{l}\text { Palma de } \\
\text { Mallorca }\end{array}$ & $10 \mathrm{~m}^{3} /$ household/month & All households & $\begin{array}{l}7 \% \text { discount on } \\
\text { prices of the two } \\
\text { first blocks }\end{array}$ & $\begin{array}{l}\text { All consumption } \\
\text { is billed at the } \\
\text { general rate }\end{array}$ \\
\hline Sabadell & $\begin{array}{l}\text { Households with } 3 \\
\text { members or fewer: } 6 \\
\mathrm{~m}^{3} / \text { household/month } \\
\text { Households with } 4 \text { or more } \\
\text { people ( } 2 * \text { household size) } \\
\mathrm{m}^{3} / \text { household/month }\end{array}$ & All households & $\begin{array}{l}\text { UVT } 0.4839(1.77 \% \\
\text { discount on the } \\
\text { price of the first } \\
\text { block) }\end{array}$ & $\begin{array}{l}\text { All consumption } \\
\text { is billed at the } \\
\text { general rate }\end{array}$ \\
\hline
\end{tabular}

Source: authors' calculations 


\section{Water tariffs for Non-residential Users}

In most of the Spanish cities analysed, there are different categories of non-residential water tariffs: a tariff for industrial users (usually includes businesses and other services) and a set of tariffs for specific uses such as fire protection, construction works, public sector, gardening etc. Among the Spanish cities with more than 100,000 inhabitants, only Castellón de la Plana has a single tariff for all uses (residential and non-residential).

\section{The Industrial Tariffs}

As with residential users, industrial users typically have a two-part tariff with a fixed and a volumetric charge. Moreover, the fixed charge is also based on the meter size. However, in some cities the non-residential users pay a higher fixed charge than residential users for the same meter size. This means that industrial users (who pay more for the same connection) bear a higher proportion of the costs covered by the fixed charge than residential users. Table 12 presents the ratio between the industrial and residential fixed charge $(r)$ in the major Spanish cities (more than 100,000 inhabitants and/or provincial capitals) for the three meter sizes $(13 \mathrm{~mm}, 20 \mathrm{~mm}$ and $40 \mathrm{~mm})$ commonly used for residential and nonresidential uses.

Table 12. Ratio ( $r$ ) of Industrial fixed charge/Residential fixed charge: number of cities

\begin{tabular}{|c|c|c|c|c|}
\hline \multirow[t]{2}{*}{ Meter size } & \multirow[t]{2}{*}{$r=1$} & \multicolumn{3}{|c|}{$r>1$} \\
\hline & & $1<r \leq 2$ & $2<r \leq 5$ & $r>5$ \\
\hline $13 \mathrm{~mm}$ & 43 & 21 & 10 & 2 \\
\hline $20 \mathrm{~mm}$ & 41 & 22 & 11 & 2 \\
\hline $40 \mathrm{~mm}$ & 42 & 15 & 14 & 5 \\
\hline
\end{tabular}

Source: authors' calculations 
Moreover, as with residential tariffs, most cities calculate the volumetric charge according to an IBT model or a UVT model. Table 13 presents descriptions of the volumetric charge applied in the 15 largest Spanish cities.

Table 13. Industrial water tariff structure: volumetric charge

\begin{tabular}{|c|c|c|c|c|c|c|c|}
\hline City & $\begin{array}{l}\text { Type of } \\
\text { tariff }\end{array}$ & $\begin{array}{c}\text { Number } \\
\text { of } \\
\text { blocks }\end{array}$ & $\begin{array}{c}\text { First block } \\
\text { size } \\
\left(\mathrm{m}^{3} / \text { month }\right. \\
)\end{array}$ & $\begin{array}{l}\text { Last block: } \\
\text { kink point } \\
\text { (m³/month) }\end{array}$ & $\begin{array}{c}\text { First block } \\
\text { price (p'; } \\
\left.€ / \mathbf{m}^{3}\right)\end{array}$ & $\begin{array}{c}\text { Last block } \\
\text { price (pn; } \\
\left.€ / \mathbf{m}^{3}\right)\end{array}$ & $\begin{array}{c}\text { Ratio } \\
\left(p^{n} / p^{1}\right)\end{array}$ \\
\hline Alicante & IBT & 3 & 6.00 & 16.00 & 0.02 & 1.88 & 94 \\
\hline Barcelona & IBT & 2 & \multicolumn{2}{|c|}{ Depending on meter size } & 1.27 & 1.90 & 1.50 \\
\hline Bilbao & IBT & 3 & 26.67 & 166.67 & 1.21 & 1.29 & 1.07 \\
\hline Córdoba & UVT & - & - & - & - & - & - \\
\hline Gijón & IBT & 3 & 15.50 & 25.00 & 0.43 & 0.57 & 1.29 \\
\hline Madrid & IBT & 3 & \multicolumn{2}{|c|}{ Depending on meter size } & 0.13 & 0.50 & 3.76 \\
\hline Málaga & UVT & - & - & - & - & - & - \\
\hline Murcia & UVT & - & - & - & - & - & - \\
\hline Palma de Mallorca & UVT & - & - & - & - & - & - \\
\hline Las Palmas de Gran Canaria & IBT & 3 & 5.50 & 14.00 & 1.21 & 3.17 & 2.62 \\
\hline Sevilla & UVT & - & - & - & - & - & - \\
\hline Valencia & IBT & 2 & 6.00 & 6.00 & 0.47 & 0.55 & 1.17 \\
\hline Valladolid & IBT & 5 & 6.67 & 45 & 0.34 & 0.80 & 2.38 \\
\hline Vigo & IBT & 6 & 15.00 & 250.00 & 0.73 & 1.45 & 1.99 \\
\hline Zaragoza & IBT & 2 & 18.48 & 18.48 & 0.50 & 1.38 & 2.75 \\
\hline
\end{tabular}

Note: For simplicity, all figures are reported with two decimals Legend: IBT: Increasing block tariff; UVT: Uniform Volumetric Tariff Source: authors' calculations

As can be seen in Table 12, and unlike in the residential water sector, UVT models are a fairly common option for industrial water tariff designs. Thus, in five of the cities analysed, the volumetric charge of the non-residential tariff is based on a UVT structure. This means that every $\mathrm{m}^{3}$ consumed is billed at the same rate. The remaining cities have adopted an IBT model, with quite a similar design in most cities. Except in Valladolid and Vigo, the most common structures have 2 or 3 blocks, and the first block is usually not particularly large. However, when looking at the kink point corresponding to the last block, the differences are greater, ranging from $6 \mathrm{~m}^{3} /$ month in Valencia to $250 \mathrm{~m}^{3} /$ month in Vigo. 
The IBT tariff design in Madrid is unique in that the size of the different blocks depends on the meter size (the greater the diameter, the greater the size of the blocks).

As with residential tariffs, IBTs are aimed at discouraging excessive water

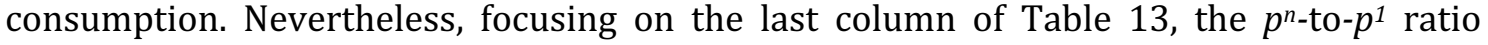
registers a lower value than that for residential users (see Table 2). This implies that the overconsumption penalty is higher for residential users than for non-residential users (for instance, in Alicante, the price of the last block is 256 times the price of the first block for residential uses, but 95 times higher in the case of non-residential users). This suggests that non-residential users have fewer incentives to save water than residential users. In short, non-residential water tariff design tends to benefit large consumers.

To offer a deeper understanding of this issue, Table 14 displays the ratio between the prices charged to non-residential and those charged to residential users, in both the first and last block. In the first block, the ratio is equal to or greater than 1 in all the cities. Conversely, when considering the last block price for both non-residential and residential users, the ratio is generally below 1 or close to 1 (the highest value registered is 1.21 in Valladolid). These figures suggest that non-residential users' burden decreases when water consumption increases. 
Table 14. Non-residential prices vs. residential prices.

\begin{tabular}{|c|c|c|}
\hline City & $\begin{array}{c}\text { Ratio first block } \\
\left.\text { prices ( } \mathbf{p}^{1} \text { nres }^{\prime} / \mathbf{p}^{1}{ }^{\text {res }}\right)\end{array}$ & $\begin{array}{c}\text { Ratio last block } \\
\text { prices }\left(\mathbf{p}^{n_{n r e s}} / \mathbf{p}^{n_{\text {res }}}\right)\end{array}$ \\
\hline Alicante & 2.00 & 0.73 \\
\hline Barcelona & 2.08 & 0.62 \\
\hline Bilbao & 2.14 & 1.04 \\
\hline Córdoba & 1.33 & 0.86 \\
\hline Gijón & 1.15 & 0.79 \\
\hline Madrid & 1.00 & 1.00 \\
\hline Málaga & 3.53 & 0.52 \\
\hline Murcia & 1.41 & 0.53 \\
\hline Palma de Mallorca & 1.55 & 0.16 \\
\hline Las Palmas de GC & 1.00 & 1.00 \\
\hline Sevilla & 1.34 & 0.41 \\
\hline Valencia & 1.00 & 1.00 \\
\hline Valladolid & 1.63 & 1.21 \\
\hline Vigo & 1.89 & 1.09 \\
\hline Zaragoza & 2.39 & 1.09 \\
\hline
\end{tabular}

Furthermore, the values displayed in the last column of Table 12 are low (except in Madrid and Alicante), showing low levels of water tariffs progressivity for non-residential users in Spain. In Table 15, the Liability Progression Index (LPI) (Musgrave and Thin, 1948) corresponding to three standard water consumption levels is presented: $10 \mathrm{~m}^{3} / \mathrm{month}$ (e.g., a small trading business), $150 \mathrm{~m}^{3} /$ month (e.g., a cafeteria), 1,500 m³/month (e.g., a factory). This index is calculated as the ratio between the marginal price and the average price for each level of consumption. If the LPI is equal to 1 , then the tariff is proportional; if the LPI is higher than 1 , then the tariff is progressive; and if the LPI is lower 1 , then the tariff is regressive.

As can be seen in Table 15, the LPI decreases as consumption increases in all cities where the volumetric charge corresponds to an IBT structure, except in Valladolid. This implies that the tariff progression is smaller for higher consumption levels. Furthermore, the LPI values that do exceed 1 (progressive tariff) are close to 1 (except in Alicante for low consumption levels); that is, they are almost proportional. For high consumption levels, the LPI values are lower than 1 (regressive tariff), i.e. in cities such as Barcelona or Madrid. 
Summarizing, the LPI shows that non-residential water tariffs clearly benefit highconsumption users.

Table 15. Liability Progression Index (LPI) for non-residential tariffs

\begin{tabular}{|c|c|c|c|}
\hline \multirow[b]{2}{*}{ City } & \multicolumn{3}{|c|}{ Consumption level } \\
\hline & $10 m^{3} /$ month & $150 \mathrm{~m}^{3} /$ month & $\begin{array}{c}1,500 m^{3} / \text { mont } \\
h\end{array}$ \\
\hline Alicante & 2.44 & 1.07 & 1.04 \\
\hline Barcelona & 1.00 & 1.10 & 0.33 \\
\hline Bilbao & 1.00 & 1.01 & 1.00 \\
\hline Córdoba & 1.00 & 1.00 & 1.00 \\
\hline Gijón & 1.00 & 1.03 & 1.00 \\
\hline Madrid & 1.00 & 1.65 & 0.68 \\
\hline Málaga & 1.00 & 1.00 & 1.00 \\
\hline Murcia & 1.00 & 1.00 & 1.00 \\
\hline Palma de Mallorca & 1.00 & 1.00 & 1.00 \\
\hline $\begin{array}{l}\text { Las Palmas de } \\
\text { GranCanaria }\end{array}$ & 1.30 & 1.04 & 1.00 \\
\hline Sevilla & 1.00 & 1.00 & 1.00 \\
\hline Valencia & 1.10 & 1.01 & 1.00 \\
\hline Valladolid & 0.16 & 0.72 & 0.96 \\
\hline Vigo & 1.00 & 1.06 & 0.95 \\
\hline Zaragoza & 1.00 & 1.09 & 1.01 \\
\hline $\begin{array}{l}\text { LPI }=1 \text { Tariff is pro } \\
\text { LPI }<1 \text { Tariff is regr } \\
\text { LPI }>1 \text { Tariff is pro } \\
\text { Source: authors' ca }\end{array}$ & $\begin{array}{l}\text { oportional } \\
\text { cessive } \\
\text { gressive } \\
\text { lculations }\end{array}$ & & \\
\hline
\end{tabular}

Specific Tariffs

In many cities, in addition to the generic structure for non-residential users, there is a wide variety of specific tariffs applied to non-residential users other than industrial uses. Table 16 displays a summary of the special tariffs in place in the 15 largest Spanish cities. 
Table 16. Specific tariffs for non-residential uses

\begin{tabular}{|c|c|c|c|c|c|c|c|c|c|c|c|c|}
\hline City & $\begin{array}{c}\text { Agriculture } \\
\text { and } \\
\text { livestock }\end{array}$ & CommerceHospitality & $\begin{array}{c}\text { Construction } \\
\text { works }\end{array}$ & $\begin{array}{l}\text { n Public } \\
\text { Sector }\end{array}$ & $\begin{array}{c}\text { NGOs/ } \\
\text { Social } \\
\text { uses }\end{array}$ & $\begin{array}{c}\text { City } \\
\text { Council }\end{array}$ & $\begin{array}{c}\text { Fire } \\
\text { Protection }\end{array}$ & $\begin{array}{l}\text { Irrigation } \\
\text { of parks } \\
\text { and } \\
\text { gardens }\end{array}$ & $\begin{array}{l}\text { Night } \\
\text { rate }\end{array}$ & $\begin{array}{c}\text { Uses } \\
\text { related } \\
\text { to } \\
\text { common } \\
\text { areas } \\
\end{array}$ & $\begin{array}{l}\text { Non- } \\
\text { potable } \\
\text { n water }\end{array}$ & $\begin{array}{c}\text { Water } \\
\text { supplied to } \\
\text { other } \\
\text { municipalities }\end{array}$ \\
\hline Alicante & & & & & & 2 & & & & & 4 & \\
\hline Barcelona & & 1 & & & & & & & & 2 & & \\
\hline Bilbao & 2 & & & & & 1 & & & & & & \\
\hline Córdoba & & & & & 1 & 4 & & & & & & \\
\hline Gijón & & & $4^{\mathrm{a}}$ & & & 2 & $4^{b}$ & & & & 2 & \\
\hline Madrid & & & & & & & & 2 & & & & \\
\hline Málaga & & & & 1 & & & & & & & 1 & 1 \\
\hline Murcia & & & & & 1 & 1 & 1 & 4 & & 1 & 4 & \\
\hline Palma de Mallorca & & 2 & & & & & 3 & & & & 1 & \\
\hline Las Palmas de Gran Canaria & & & & $1^{\mathrm{c}}$ & $1^{c}$ & & & & & & & \\
\hline Sevilla & & & & 1 & 1 & & 1 & $1^{\mathrm{d}}$ & $1^{e}$ & & & \\
\hline Valencia & & & & & & 4 & $4^{b}$ & & & & & \\
\hline Valladolid & & & $3^{f}$ & & & & & & & & & 4 \\
\hline Vigo & & & $4 \mathrm{~g}$ & & & & $4^{b}$ & & & & & \\
\hline Zaragoza & & & $2^{\mathrm{h}}$ & & & & & & & 2 & & \\
\hline
\end{tabular}

1 = Two-part tariff: Fixed charge + UVT; 2 = Two-part tariff: Fixed charge + IBT; 3 = One-part tariff: Flat rate; 4 = One-part tariff: Volumetric charge (UVT).

a The volumetric charge is a uniform price per day. This tariff is only for construction works lasting less than 15 days.

b The volumetric charge is a uniform price for each fire hydrant installed.

c With a minimum consumption of $10 \mathrm{~m}^{3}$.

d Efficient irrigation.

e Industrial users with a diameter meter equal to or greater than $80 \mathrm{~mm}$. This tariff is for consumption metered between 10 p.m and 6 a.m. in a specific meter.

$f$ There are different flat rates depending on the area of the construction works.

$\mathrm{g}$ The volumetric charge is a uniform price for each connection to the network.

h Only for commerce, hospitality and repair activities (i.e. vehicles) with a daily consumption less than $0.750 \mathrm{~m}^{3}$ affected by construction works on their street. There are different IBTs depending on the duration of the construction works.

Source: authors' calculations 
Table 16 shows that each city designs different specific tariffs according to arbitrary criteria. In some cases, these specific tariffs can be justified by the relevance of a particular use in the city in question (e.g. the Commerce tariff in Barcelona or the Hospitality tariff in Palma de Mallorca). Moreover, there are uses that are time-limited (e.g. construction works) or periodic (e.g. fire protection), so a different tariff is applied. In some cases, the special tariffs are justified since the use is considered a different service (non-potable water). In other cases, such as City Council (e.g. municipal buildings, irrigation of public areas) or Public Sector use (Regional and/or Central government buildings) there is nothing to justify the application of a specific tariff, which means that the efficiency and equity criteria are probably being broken.

Furthermore, in most cases, the volumetric charge is a UVT, so there is less incentive to conserve water than in the case of residential users, whose tariffs are based on an IBT structure. In Table 17 a comparison of the fixed charge and the average price of a cubic meter of water for the residential tariff, industrial tariff and three specific tariffs is presented. 
Table 17. Specific tariffs vs residential and industrial tariffs

\begin{tabular}{|c|c|c|c|c|c|}
\hline \multirow{2}{*}{ City } & \multicolumn{5}{|c|}{ Fixed charge (13mm meter) } \\
\hline & Residential & Industrial & Public Sector & $\begin{array}{c}\text { NGOs/ } \\
\text { Social Uses }\end{array}$ & City Council \\
\hline Alicante & 7.67 & 7.67 & & & 7.67 \\
\hline Bilbao & 2.21 & 2.21 & & & 2.21 \\
\hline Córdoba & 3.87 & 4.16 & & 4.16 & 0.00 \\
\hline Gijón & 2.70 & 2.70 & & & 2.70 \\
\hline Málaga & 2.55 & 2.55 & 2.55 & & \\
\hline Murcia & 6.90 & 6.90 & & 6.90 & 6.90 \\
\hline Las Palmas de Gran Canaria & 5.20 & 5.20 & 12.29 & 5.47 & \\
\hline Sevilla & 3.86 & 3.86 & & 3.86 & 3.86 \\
\hline Valencia & 3.31 & 3.31 & & 0.00 & 0.00 \\
\hline
\end{tabular}

\begin{tabular}{|c|c|c|c|c|c|}
\hline \multirow{2}{*}{ City } & \multirow[b]{2}{*}{ Residential } & \multirow[b]{2}{*}{ Industrial } & \multirow[b]{2}{*}{ Public Sector } & \multirow[b]{2}{*}{$\begin{array}{c}\text { NGOs/ } \\
\text { Social Uses }\end{array}$} & \multirow[b]{2}{*}{ City Council } \\
\hline & & & & & \\
\hline Alicante & 0.35 & 0.52 & & & 0.20 \\
\hline Bilbao & 0.59 & 1.21 & & & 0.53 \\
\hline Córdoba & 0.82 & 1.06 & & 0.74 & 1.06 \\
\hline Gijón & 0.38 & 0.44 & & & 0.35 \\
\hline Málaga & 0.94 & 0.74 & 0.74 & & \\
\hline Murcia & 1.11 & 1.39 & & 0.31 & 0.31 \\
\hline Las Palmas de Gran Canaria & 1.60 & 1.69 & 1.23 & 1.09 & \\
\hline Sevilla & 1.09 & 0.67 & 0.47 & 0.47 & \\
\hline Valencia & 0.50 & 0.50 & & & 0.49 \\
\hline
\end{tabular}

Note: For simplicity, all figures are reported with two decimals Source: authors' calculations

As shown in the top half of Table 17 the fixed charge for a $13 \mathrm{~mm}$ meter is the same for all non-residential uses (industry and other users), except in Las Palmas de Gran Canaria, where the fixed charge paid by the Public Sector is more than double that for residential and industrial uses, and in Córdoba and Valencia, where the City Council does not pay any fixed charge. These charges are equal or very similar to those for residential users. Conversely, in the bottom half of Table 17, it can be seen that, except in the case of Córdoba City Council, the average price per $\mathrm{m}^{3}$ paid by City Councils is lower than the price paid by residential or industrial users. Indeed, in some cases such as Murcia, $1 \mathrm{~m}^{3}$ of water costs 3.5 times more for residential users (and about 4 times more for industrial users) than for the City Council 
or some Non Governmental Organizations. This implies the existence of cross-subsidization among different users, meaning that households and industries are financing the water consumed by the City Council or the Public Sector, among other users. This situation violates the efficiency and/or equity principles in water pricing.

\section{Conclusions}

Water pricing has been traditionally considered a powerful tool for fulfilling several aims in the water sector (OECD, 2003, 2010). However, the more goals are set, the greater the complexity observed. Spain is not an exception; indeed, the achievement of equity, efficiency and environmental aims (among others) has given rise to a convoluted picture in terms of water tariff structures and levels. The research carried out in this chapter, exclusively focused on water supply tariffs at the 15 largest cities in the country, has revealed the enormous complexity of the Spanish system. The strong degree of heterogeneity observed reflects the ability of sub-central governments to adapt the general pricing rules to specific groups or situations. However, some proposals emerge from our study:

- First of all, the wide variety of special tariffs applied in many Spanish cities is not always justified in terms of the equity principle. The analysis of these tariffs shows that social tariffs and the tariffs applied to large families are not necessarily well designed, since they do not contribute to significant improvements in the income distribution, and in some cases run counter to the equity principle. For example, some designs of special tariffs for large families result in additional benefits going to a portion of households that are already receiving more favourable treatment under the general tariff. In light of these problems, it would be advisable to design some ex-post grant mechanisms to deal with equity issues (especially for lowincome households). Moreover, when it comes to accounting for family size in residential tariffs, a per capita structure could be proposed as an alternative to the general tariff. 
- Second, eligibility criteria for special tariffs add more complexity to the tariff system and adversely affect horizontal equity. The clearest example is found in cities where special tariffs only benefit accredited large families. This prevents some large households from accessing the special tariffs, but allows access for some small households (in special cases; for example, if one child is disabled, a three-person household may qualify as a large household). Similarly, when social tariffs stipulate an age requirement, some low-income households can be excluded from accessing them.

- Third, not enough incentives are provided to preserve water resources, since fairly little progression between pricing blocks is detected for certain users. Thus, nonresidential users are commonly charged through UVT or low-progression IBT schemes. Indeed, the presence of free allowances in some cases disincentivizes water-saving behaviour. While still maintaining their autonomy, local governments could adopt some general solutions (i.e. dropping free allowances from water tariffs) that could help to address efficiency and environmental issues.

- Fourth, from an equity point of view, the fixed charge should reflect each user's consumption capacity, determined by the water meter, rather than the type of use. In many cities, the costs of being connected to the public water network are not always proportionally shared between the users, with industrial users paying a higher fixed charge than residential users for the same connection.

- Fifth, most of the specific tariffs applied in Spain are not justified on the basis of efficiency, equity or environmental purposes. A case in point is the tariff designed for the water consumption of the City Council or Regional and Central governments. Thus, there should be a significant reduction in the number of these tariffs, leaving only those-like fire protection, irrigation or construction works-that are related to water uses with specific characteristics that require different treatment. 
In short, a simplification of the tariff system is required in most cities in order to accomplish the principle of "consumer acceptability" and reduce the administrative costs of water utilities. Additionally, the heterogeneous tariff system found in most Spanish cities runs counter to equity principles and can send the wrong signal to users about water scarcity, thereby hindering compliance with the resource sustainability objective.

\section{References}

Andres, L.A:, Thibert, M., Lombana, C., Danilenko, A.V., Joseph, G. and Borja-Vega, C. (2019) Doing More with Less Smarter Subsidies for Water Supply and Sanitation, International Bank for Reconstruction and Development/The World Bank, Washington DC

Arbués, F. and Barberán, R. (2012), “Tariffs for Urban Water Services in Spain: Household Size and Equity, International Journal of Water Resources Development, 28 (1), pp.123-140

Arbués, F., García-Valiñas, M.A. and Martínez-Espiñeira, R. (2003), “Estimation of residential water demand: a state-of-the-art review" Journal of Socio-Economics, 32 (1), pp.81102.

Arbués, F., Villanúa, I. and Barberán, R. (2010), "Household size and residential water demand: an empirical approach", Australian Journal of Agricultural and Resource Economics, 54(1), pp.61-80

Arbués, F., Bolsa, M.A. and Villanúa, I. (2016), "Which factors determine water saving behaviour? Evidence from Spanish households", Urban Water Journal, 13, pp. 511$520-$

Arbués, F., Sanaú, J. and Serrano, J.M. (2017), “El precio del agua en las ciudades: efectos del modelo de gestión", Papeles de Economía Española, 153, pp.48-64. 
BOE (2003) Law 40/2003 of 18 November, on Protection of Large Families https://www.boe.es/boe/dias/2003/11/19/pdfs/A40845-40852.pdf

Bös, D. (1985), “Public sector pricing”. In: A. J. Auerbach y M. Feldstein (eds.) Handbook of Public Economics, North Holland, Amsterdam: Elsevier Science, vol. I, pp.129-211.

Calatrava, J., García-Valiñas, M.A., Garrido, A., and González-Gómez, F.J., (2015), “Water pricing in Spain: Following the footsteps of somber climate change projections", in Water Pricing Experiences and Innovations, Springer.

Campbell. H.E., Johnson, R.M. and Larson, E.H. (2004), “Prices, Devices, People, or Rules: The Relative Effectiveness of Policy Instruments in Water Conservation", Review of Policy Research, 5, pp. 637-662.

Castro, F., Da-Rocha, J.M. y Delicado, P. (2002), “Desperately seeking 0's: estimating the distribution of consumers under increasing block rates", Journal of Regulatory Economics, 22(1), pp.29-58.

EC (2000) Directive 2000/60/EC of the European Parliament and the Council of 23 October 2000 establishing a framework for Community action in the field of water policy (Official Journal of the European Communities L 327 of 22.12.2000)

García-Valiñas, M.A. (2019) “Water governance in Spain: The role of federalism and publicprivate partnerships", in Porcher, S. and Saussier, S. (Eds.), Facing the Challenges of Water Governance, pp.29-55, Palgrave Macmillan, London.

Garcia-Valiñas, M.A., Martínez-Espiñeira, R. and González-Gómez, F.J (2010), “Affordability of residential water tariffs: Alternative measurement and explanatory factors in southern Spain", Journal of Environmental Management, 91(12), pp.2696-2706. 
García-Valiñas, M.A., Martínez-Espiñeira, and To, H. (2015), "The use of non-pricing instruments to manage residential water demand: What have we learned?" in Grafton et al. (Ed.) Understanding and Managing Urban Water in Transition, pp. 269281, Springer, Dordrecht.

García-Valiñas, M.A., González-Gómez, F.J. and Picazo Tadeo, A. (2013), “Is the price of water for residential use related to ownership? Empirical evidence from Spain", Utilities Policy. 24, 59-69.

Gómez-Lobo, A., Foster, V. and Halpern, J. (2000), "Information and modelling issues in designing water and sanitation subsidy schemes", World Bank PR Working PapersInfrastructure. Telecom, power and water, 2345, World Bank, Washington DC.

INE (2013), Censos de Población y https://www.ine.es/censos2011 datos/cen11 datos inicio.htm $\quad$ (accessed 4 November 2019)

INE (2018a), Urban Indicators (Urban Audit). http://www.ine.es/jaxiT3/Tabla.htm?t=10849 (accessed 26 June 2019).

INE (2018b), Survey on Water Supply and Sewerage. http://www.ine.es/dyngs/INEbase/en/operacion.htm?c=Estadistica C\&cid=1254

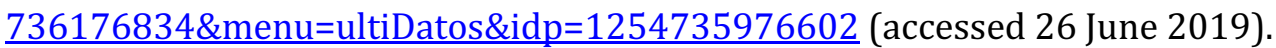

INE (2019a), Padrón. Población por http://www.ine.es/dyngs/INEbase/es/categoria.htm?c=Estadistica P\&cid=12547 $\underline{34710990}$ (accessed 26 June 2019).

INE (2019b)

Central Business Register http://www.ine.es/dynt3/inebase/en/index.htm?padre=51\&dh=1_(accessed 26 June 2019).

Komives, K., Foster,V., Halpern, J. and Wodon, Q. (2005), Water, Electricity and the Poor. Who Benefits from Utility Subsidies? World Bank, Washington D.C. 
le Blanc, D., (2009), A Framework for Analyzing Tariffs and Subsidies in Water Provision to Urban Households in Developing Countries, DESA Working Paper No. 63, United Nations Department of Economic and Social Affairs, New York.

Lee, M. and Tansel, B. (2013), "Water conservation quantities vs customer opinion and satisfaction with water efficient appliances in Miami, Florida", Journal of Environmental Management, 128, pp. 683-689

Lopez-Gunn, E., P. Zorrilla, F. Prieto, and Llamas M. (2012), "Lost in translation? Water efficiency in Spanish agriculture", Agricultural Water Management 108, pp. 83-95.

Musgrave, R.A., and Thin, T. (1948), "Income Tax Progression, 1929-1948” Journal of Political Economy, 56 (6), pp.498-514.

Nauges, C. and Whittington, D. (2017) "Evaluating the Performance of Alternative Municipal Water Tariff Designs: Quantifying the Tradeoffs between Equity, Economic Efficiency, and Cost Recovery", World Development, 91, 125-143

OECD (1987), Pricing of Water Services. OECD, Paris

OECD (2003), Social Issues in the Provision and Pricing of Water Services. OECD, Paris.

OECD (2010), Pricing Water Resources and Water Sanitation Services. OECD, Paris.

OECD (2013). Environment at a Glance (2013), OECD Indicators. OECD, Paris.

OECD (2015), Water and Cities: Ensuring Sustainable Futures, OECD Studies on Water, OECD Publishing, Paris.

Randolph, B. and Troy, P. (2008), "Attitudes to conservation and water consumption", Environmental Science \& Policy, 11 (5), pp. 441-455.

Reynaud, A. (2007), Social Policies and Private Sector Participation in Water Supply - The Case of France, Working paper, United Nations Research Institute for Social Development.

Reynaud, A. (2015), Modelling Household Water Demand in Europe, available at http://publications.jrc.ec.europa.eu/repository/bitstream/JRC96268/reportresid entialwatereu28reportjrc_v5_final_correctedforjrcstyle.pdf. 
Reynaud, A. and Romano, G. (eds.) (2018), Special Issue "Advances in the Economic Analysis of Residential Water Use", Water, 10, available at https://www.mdpi.com/journal/water/special issues/economic residential water Rogers, de Silva, R. and Bhatia, R. (2002) "Water is an economic good: How to use prices to promote equity, efficiency, and sustainability", Water Policy 4, pp.1-17

Romano G., Salvati N. and Guerrini A. (2016), "An Empirical Analysis of the Determinants of Water Demand in Italy", Journal of Cleaner Production, 130 (1), pp. 74-81.

Seguridad Social (2019), Datos por municipios. Trabajadores en alta http://www.segsocial.es/wps/portal/wss/internet/EstadisticasPresupuestosEstudios/Estadistica s/EST8/EST10/EST305/1836?changeLanguage=en

Schoengold, K. and Zilberman, D. (2014), "The economics of tiered pricing and cost functions: Are equity, cost recovery, and economic efficiency compatible goals?", Water Resources and Economics, 7, pp.1-18

Soto P.C., Deen, T.A., Nagabhatla, N. and Ayala, G. (2018), "Explaining Water Pricing through Water Security Lens", Water, 10, 1173

United Nations (2010) Resolution A/RES/64/292. United Nations General Assembly, July 2010.

United Nations, (2018). Sustainable Development Goal 6 Synthesis Report on Water and $\begin{array}{lllll}\text { Sanitation } & \text { 2018. } & \text { New } & \text { York. }\end{array}$ https://www.unwater.org/publication categories/sdg-6-synthesis-report-2018on-water-and-sanitation/

Willaarts B.A., M. Ballesteros and N. Hernández-Mora (2014), "Ten years of the Water Framework Directive in Spain: An overview of the ecological and chemical status of surface water bodies". In: P. Martínez-Santos, M. M. Aldaya and M. R. Llamas (eds.) Integrated Water Resources Management in the 21st Century: Revisiting the Paradigm. CRC Press/Balkema. Leiden, pp. 99-120. 


\section{Suggested lectures}

Banerjee, S., Foster, V., Ying, Y., Skilling, H. and Wodon, Q. (2010),. Cost Recovery, Equity, and Efficiency in Water Tariffs: Evidence from African Utilities. Policy Research working paper, WPS 5384, World Bank. Available at https://openknowledge.worldbank.org/handle/10986/3868

Barberán, R. and Arbués, (2009), "Equity in domestic water design", Water Resources Management, 23, pp.2101-2118.

EurEau (2017), Europe's water in figures An overview of the European drinking water and waste water sectors Associations of Water Services, Brussels. Available at http://www.eureau.org/resources/publications/1460-eureau-data-report-2017$1 /$ file

EurEau (2018), The Governance of Water Services in Europe, The European Federation of National Associations of Water Services, Brussels. Available at http://www.eureau.org/resources/publications/150-report-on-the-governance-ofwater-services-in-europe/file

European Environment Agency (2013) Assessment of cost recovery through water pricing EEA, Tech. rep. 16/2013. Available at https://www.eea.europa.eu/assessment-offull-cost-recovery

European Environment Agency (2019) Use of freshwater resources. Available at https://www.eea.europa.eu/data-and-maps/indicators/use-of-freshwaterresources-2/assessment-3

Martínez-Espiñeira, R., García-Valiñas, M.A. and Gonzáles-Gómez, F.J. (2012), “Is the Pricing of Urban Water Services Justifiably Perceived as Unequal among Spanish Cities?", International Journal of Water Resources Development, 29 (1), pp.107-122.

Tortajada, C., González-Gómez, F.J., Biswas, A.K. and Buurman, J., (2019), “Water demand management strategies for water-scarce cities: The case of Spain", Sustainable Cities and Society, 45, pp.649-656. 


\section{ORE cross-reference suggestions}

Environmental Regulations in Mexico; Rethinking Conflict over Water; Strategic Planning in the Public Sector; The Economics of Watershed Management; The Politics of Primary Health Care; Water; Water supply 